\title{
Pseudoscorpions (Arachnida, Chelonethi) in Mexican amber, with a list of extant species associated with mangrove and Hymenaea trees in Chiapas
}

\author{
Mark L.I. Judson ${ }^{1, *}$ \\ 'Institut de Systématique, Évolution, Biodiversité (ISYEB), UMR 7205 CNRS, MNHN, UPMC, EPHE, Muséum national d'Histoire \\ naturelle, Sorbonne Universités, 57 rue Cuvier, CP 53, 75005 Paris, France. \\ *judson@mnhn.fr
}

\begin{abstract}
Eight pseudoscorpions in amber from Chiapas State, Mexico, are described. These include the first fossil records of the tribe Tyrannochthoniini (Chthoniidae). Paraliochthonius miomaya $\mathrm{n}$. sp. is described from an adult male and a protonymph in separate pieces of amber from Simojovel. The protonymph is the first to be recorded for a species of Paraliochthonius Beier, 1956 and shows that this stage is free-living and non-regressive in this genus. The presence of a Paraliochthonius species in Simojovel amber adds support to the hypothesis that at least part of this amber is derived from a mangrove environment, since the extant epigean species of this genus are restricted to littoral habitats. An unnamed species of Tyrannochthonius Chamberlin, 1929 is described from an adult female in amber from Rio Salado, near Totolapa, Chiapas. Nymphal pseudoscorpions in amber from Simojovel are tentatively assigned to the extant genera Lustrochernes Beier, 1932 (Chernetidae) and Paratemnoides Harvey, 1991 (Atemnidae), and an unidentified genus of Cheliferini (Cheliferidae). The genus Mayachernes Riquelme, Piedra-Jiménez and Córdova-Tabares, 2014, which was erected for the first species of pseudoscorpion to be named from Mexican amber, is synonymized with Byrsochernes Beier, 1959, resulting in the new combination Byrsochernes maatiatus (Riquelme, Piedra-Jiménez and Córdova-Tabares, 2014).

A list is given of extant pseudoscorpions collected close to mangroves at La Cadena and from Hymenaea courbaril trees at Coquitos (Biosphere Reserve La Encrucijada), both in Chiapas State. These include the first Mexican records of the species Americhernes oblongus (Say, 1821) and the genus Dolichowithius Chamberlin, 1931. Paratemnoides elongatus (Banks, 1895) and Trinidatemnus separatus van den Tooren, 2008 are synonymized with P. nidificator (Balzan, 1888) (new subjective synonymies). Trinidatemnus van den Tooren, 2008 therefore becomes a junior synonym of Paratemnoides Harvey, 1991 (new subjective synonymy). The first record of P. nidificator from the Caribbean island of Guadeloupe is given.
\end{abstract}

Keywords: pseudoscorpions, amber, mangroves, Mexico, Chiapas, Miocene.

Resumen

Se reportan ocho pseudoescorpiones en ámbar de Chiapas, México. Éstos incluyen el primer registro fósil de la tribu Tyrannochthoniini (Chthoniidae). Se describe un macho adulto y una protoninfa de Paraliochthonius miomaya n. sp. en piezas separadas de ámbar de la localidad de Simojovel. La protoninfa es la primera en ser citada para una especie de Paraliochthonius Beier, 1956 y muestra que en ese estadio es de vida libre y no regresiva en este género. La presencia de una especie de Paraliochthonius en el ámbar de Simojovel apoya la hipótesis de que al menos parte de este ámbar se deriva de un entorno de manglar, ya que las especies epigeas actuales de este género están restringidas a hábitats litorales. Una especie innominada de Tyrannochthonius Chamberlin, 1929 se describe de una hembra adulta en el ámbar de Río Salado, cerca de Totolapa (Chiapas). Ninfas de pseudoescorpiones en el ámbar de Simojovel son provisionalmente asignadas al género actual Lustrochernes Beier, 1932 (Chernetidae) y Paratemnoides Harvey, 1991 (Atemnidae), y un género no identificado de Cheliferini (Cheliferidae). El género Mayachernes Riquelme, Piedras-Jiménez y Córdoba-Tabari, 2014, que fue erigida para la primera especie de pseudoescorpión identificada en el ámbar mexicano, es sinonimizada con Byrsochernes 
Beier, 1959, dando lugar a la nueva combinación Byrsochernes maatiatus (Riquelme, Piedras-Jiménez y Córdoba-Tabari, 2014).

Se presenta una lista de pseudoescorpiones existentes recogidos cerca de los manglares de La Cadena y en árboles de Hymenaea courbaril en Coquitos (Reserva de la Biosfera La Encrucijada), ambos en el estado de Chiapas. Éstos incluyen los primeros registros mexicanos de la especie Americhernes oblongus (Say, 1821) y del género Dolichowithius Chamberlin, 1931. Paratemnoides elongatus (Banks, 1895) y Trinidatemnus separatus van den Tooren, 2008 son sinonimizidas con P. nidificator (Balzan, 1888) (nuevas sinonimias subjetivas). Trinidatemnus van den Tooren, 2008 se convierte, por lo tanto, en un sinónimo menor de Paratemnoides Harvey, 1991 (nueva sinonimia subjetiva). El primer registro de P. nidificator se aporta para la isla caribeña de Guadeloupe.

Palabras clave: pseudoescorpiones, ámbar, manglares, México, Chiapas, Mioceno.

\section{Introduction}

Mexican amber has traditionally been mined at Simojovel, in the state of Chiapas, but in recent years material has been collected at the village of Rio Salado, near Totolapa, in the same state. This amber, termed Simojovelite by Riquelme et al. (2014b), is considered to date from the Lower or Middle Miocene (15-20 My) at both sites (Solórzano Kraemer, 2007, 2010; Perrilliat et al., 2010; Durán-Ruiz et al., 2013), which are about $65 \mathrm{~km}$ apart. The resin is thought to have been produced by Hymenaea trees in a tropical dry forest near the coast, partly associated with mangroves (Langenheim et al., 1967; Solórzano Kraemer, 2007, 2010).

The first pseudoscorpion to be reported from Mexican amber was a protonymph of the extant family Chernetidae, described by Schawaller (1982). The immaturity of the specimen precluded its assignment to a genus, but Schawaller (1982) speculated that it might be related to the genus Pachychernes Beier, 1932. Boucot and Poinar (2010) illustrated an unidentified pseudoscorpion phoretic on a bark beetle (Scolytinae) in Mexican amber. Photographs of other specimens, identified here as probably belonging to the genus Lustrochernes Beier, 1932, have been published by Solórzano Kraemer and Rust (2006), Solórzano Kraemer (2007), Solórzano Kraemer and Stebner (2013) and Ross and Sheridan (2013). Recently, Riquelme et al. (2014a) have described a new genus and species of Chernetidae from a well preserved male in amber from Simojovel, this being the first pseudoscorpion to be named from Mexican amber.

During the past few years I have received several pseudoscorpions in Mexican amber for study. These are reported here and, although not all are in suitable condition to be identified, they are notable for including the first fossil representatives of the tribe Tyrannochthoniini and the first fossil species of a halophile pseudoscorpion group, namely the genus Paraliochthonius Beier, 1956.

As part of an investigation into the affinities between the Simojovel amber fauna and that of modern mangroves, Solórzano Kraemer and Stebner (2013) and Solórzano Kraemer et al. (2015) sampled extant taxa from mangroves at Coquitos and La Cadena (Chiapas). The pseudoscorpions obtained during that study are also identified here.

\section{Materials and methods}

Most of the fossil material examined here comes from the mines at Simojovel de Allende, in the state of Chiapas, Mexico. Accounts of the stratigraphy of this site can be found in Solórzano Kraemer $(2007,2010)$. One specimen comes from the mines at Rio Salado, near Totolapa. The stratigraphy of this site is described by Coty et al. (2014).

One specimen (SMNS Mx-388.4) had been embedded in synthetic resin before being received for study. Other specimens were received in different states of preparation. A few of these were additionally prepared by sanding and polishing with a fine aluminium paste and a Chamois leather. A small piece of coverslip was placed on the surface of the amber, directly above the specimen to be examined, with a thin layer of glycerine between the coverslip and the amber. This reduced optical distortions due to irregularities or curvature of the amber surface.

It should be noted that most of the fossils examined here show different degrees of deformation. In general this takes the form of a stretching of parts along one axis, usually the disto-proximal, resulting in unnaturally high length/breadth ratios of the appendages and body. However, such stretching can also occur transversally, with the opposite effect. Some of the effects are similar to those observed for autoclaved amber specimens, especially the increase in relative length of setae, which do not contract as much as other parts (Hoffeins, 2012). Distortion of Mexican amber fossils has been attributed to heating as a result of volcanic activity in the region (Solórzano Kraemer, 2007, 2010).

Extant material from Chiapas was collected from two localities with different habitats: La Cadena, from 3 Bursera simaruba trees close to a coastal mangrove; and Coquitos, from 3 Hymenaea courbaril trees close to a river, about 10 $\mathrm{km}$ inland from La Cadena (Solórzano Kraemer and Stebner, 2013). Various types of traps were used, as described by Solórzano Kraemer and Stebner (2013) and Solórzano Kraemer et al. (2015). The material was preserved in $70 \%$ alcohol. Specimens were examined as temporary mounts in glycerine in a cavity slide. Genitalia were examined in specimens partially cleared in cold $10 \% \mathrm{KOH}$, rinsed in 
distilled water and then temporarily mounted in $50 \%$ lactic acid, after which they were again rinsed in distilled water and returned to alcohol for preservation.

Observations and drawings were made with a Leitz Laborlux S microscope equipped with a drawing tube. The same equipment was used to examine the fossil and extant specimens, except that long working-distance objectives were used to examine the amber material. Measurements were taken with an ocular micrometer using the reference points proposed by Chamberlin (1931). Measurements are expressed as length $\times$ breadth (unless otherwise indicated), followed by ratios in parentheses. For the chela; measurements including pedicel are marked "+" and those without "'-. (Judson, 2007). Positions of setae or trichobothria are measured from their centre (corresponding to the insertion of the hair). Measurements of inclined parts in amber specimens were corrected by trigonometry ( $\mathrm{Z}$ values obtained using calibrated focus of microscope). Because most of the specimens examined here are strongly distorted, the measurements and proportions obtained are of rather limited value for identifying the species. Terminology generally follows Chamberlin (1931), with modifications by Gabbutt and Vachon (1963) for Chthoniidae. The tactile setae of the chelal palm follow Mahnert (1978), except that upper case letters are used because identical designations have been used for microsetae (Vachon, 1963).

Photographs were taken at successive focal planes using a Nikon 995 Coolpix camera mounted on a Wild M5A stereomicroscope and the images stacked using the program CombineZP (distributed by A. Hadley at http:// www.hadleyweb.pwp.blueyonder.co.uk).

\subsection{Depository acronyms/codes}

- CNAN-UNAM: Colección Nacional de Arácnidos (CNAN), Universidad Nacional Autónoma de México (UNAM), México.

- IHNFG: Museo de Paleontología Eliseo Palacios Aguilera, Instituto de Historia Natural y Ecología, Tuxtla Gutiérrez ['FG' in the collection code refers to "Fósil Geográfico"].

- MNHN: Muséum national d'Histoire naturelle, Paris.

- NMS: National Museum of Scotland, Edinburgh.

- SMF: Senckenberg Forschungsinstitut und Naturmuseum, Frankfurt.

- SMNS: Staatliches Museum für Naturkunde, Stuttgart.

\subsection{ZooBank registration}

The present work has been added to the Official Register of Zoological Nomenclature through registration in ZooBank (http://zoobank.org/References/E5D1573BDE71-4FE4-BF5E-6C39AE3020A5).

\section{Systematic palaeontology}

\author{
Superorder Pseudoscorpiones Latreille, 1817 \\ Order Chelonethi Thorell, 1883 \\ Superfamily Chthonioidea Daday, 1889 \\ Family Chthoniidae Daday, 1889
}

Remarks. The publication date of Chthoniidae (and coordinate names) is often given as 1888 , but Daday's (1889a, 1889b) papers were published on 15 Jan. 1889, as printed on the wrapper of the combined fascicule (3-4) in which they appear. Two versions of the work, one in Hungarian and the other in German, were published simultaneously. Because they have their own title and authorship, and are not printed consecutively within the fascicule, it is more convenient to treat the two versions as separate papers, rather than as parts of a single paper, even though they share the same plate.

Tribe Tyrannochthoniini Chamberlin, 1962

Remarks. The tribe Tyrannochthoniini previously lacked a fossil record. Judson (2010) recorded an unidentified species of Tyrannochthonius in Madagascan copal and noted that species of this extant genus, which is very common and widespread in the modern tropics and subtropics, could be expected be to found in Dominican and Mexican ambers. This is confirmed here by the discovery of the Tyrannochthonius sp. treated below. More surprising is the discovery of two fossils of Paraliochthonius, which also belongs to Tyrannochthoniini, since extant species of this genus are limited to either littoral habitats or caves.

Genus Paraliochthonius Beier, 1956

Paraliochthonius miomaya n. sp.

urn:1sid:zoobank.org:act:8590E138-7DD8-4A8D-AE8B-AA6C990EF290 Figures 1-13, 31-32

Material examined. Holotype $\delta$ (IHNFG-5299) in small $(8 \times 5 \times 5 \mathrm{~mm})$, cuboid offcut of amber from Chiapas, Mexico. Paratype protonymph (IHNFG-5300) in small (7× $6 \times 3 \mathrm{~mm}$ ), cuboid offcut of amber from same piece as the holotype. The original piece of amber from which the types were cut also contained an isopod, an amphipod (Talitridae), fragments of ants and other undetermined insects (T.A. Hegna, in litt.). The holotype is strongly distorted and the appendages have a much more elongate appearance than they would have had in the living animal. The paratype protonymph has been compressed, resulting in a general dorsoventral flattening.

Diagnosis (adult). Fossil Paraliochthonius with two spiniform setae on paraxial face of chelal palm, the posterior one of which is inserted slightly behind middle of palm, and another paraxial spiniform at the base of the fixed finger. Trichobothrium ist clearly distad of $e s b$; trichobothrium 


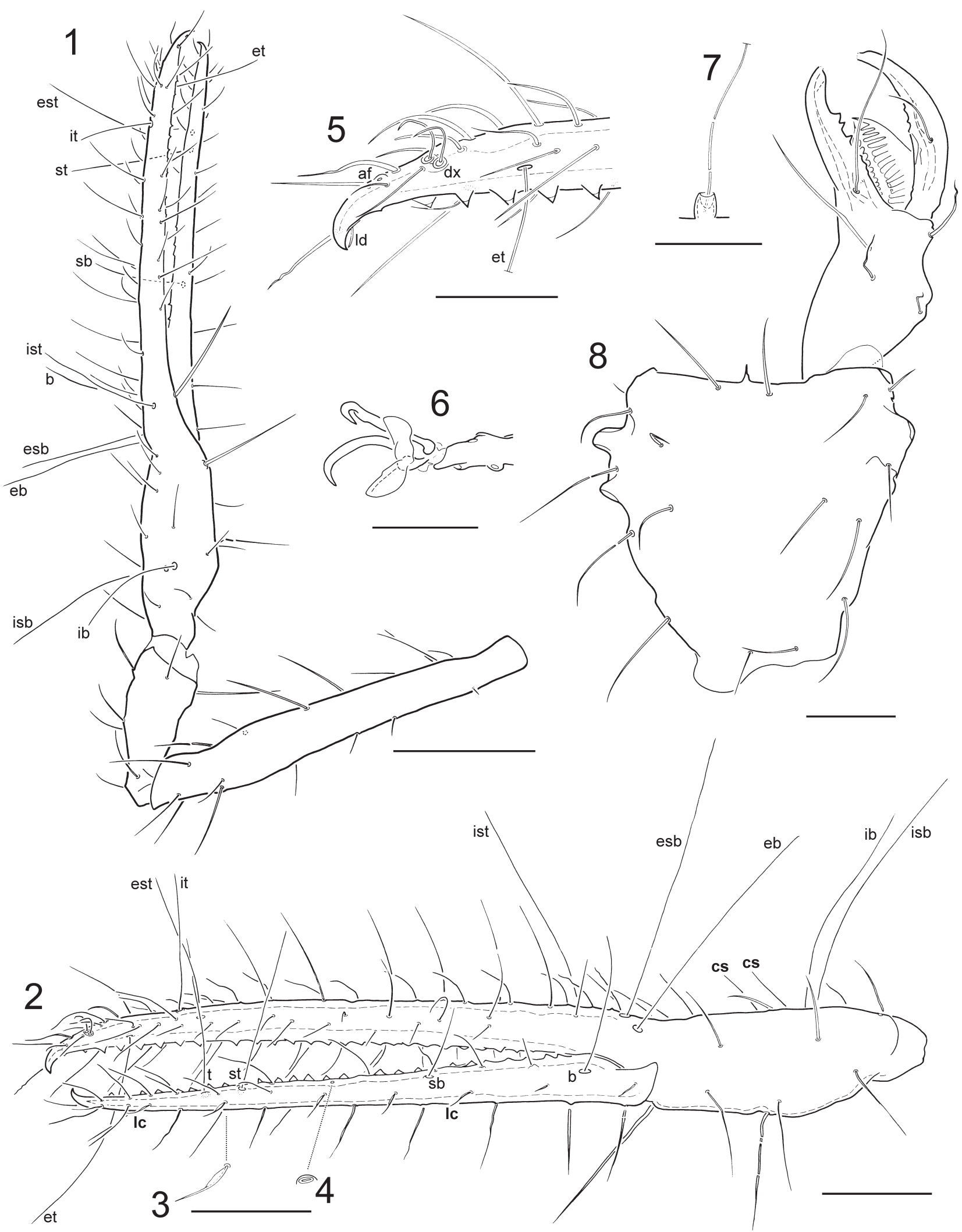

Figures 1-8. Holotype male of Paraliochthonius miomaya n. sp., in amber from Simojovel. 1, left palp, near-dorsal view; 2, left chela, near-lateral (slightly ventral) view; 3 , foliate seta of movable chelal finger; 4 , sensillum ( $p_{2}$ ?) of movable chelal finger; 5 , tip of fixed finger of left palp, near-lateral (slightly ventral) view; 6, tip of tarsus and apotele of right leg II, near-ventral (slightly distal and paraxial) view, most setae omitted; 7, tactile seta on right side of tergite XI (only basal part of hair shown), dorsal view; 8 , carapace and right chelicera, dorsal view. Abbreviations: $a f$, apical sensilla of fixed chelal finger; $c s$, chemosensory setae; $l c$, lanceolate setae; ld, lamina defensor; other abbreviations are designations of individual trichobothria. Scale lines: 0.2 $\mathrm{mm}$ (Figure 1), $0.1 \mathrm{~mm}$ (Figures 2, 8), $0.05 \mathrm{~mm}$ (Figures 3-7). 


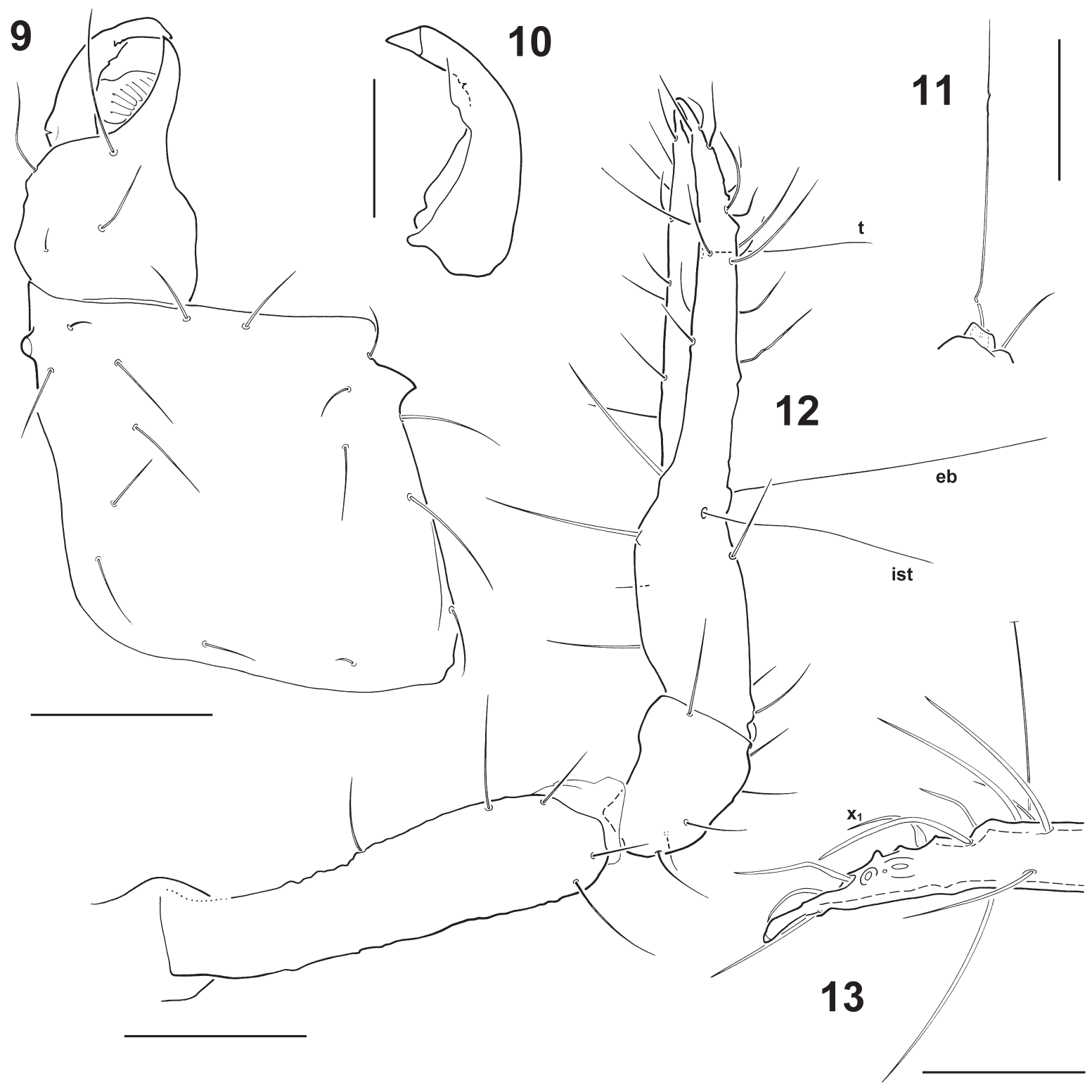

Figures 9-13. Paratype protonymph of Paraliochthonius miomaya n. sp. in amber from Simojovel. 9, carapace and left chelicera, dorsal view; 10, movable finger of right chelicera; 11, right tactile seta and adjacent normal seta on tergite XI, dorsal view; 12, right palp, near dorsal view; 13, tip of fixed finger of right chela, dorsal view. Abbreviations: are designations of individual trichobothria. Scale lines: $0.1 \mathrm{~mm}$ (Figures 9, 12), $0.05 \mathrm{~mm}$ (Figures 10, 11, 13).

$s b$ half-way between $b$ and st. Movable chelal finger with several lanceolate seta on antiaxial face; chelal fingers each with 27-29 aligned and well spaced teeth.

Etymology. A combination of the Greek word meios (meaning less), with reference to the Miocene, and Maya, the name of the ancient Mesoamerican civilization that inhabited southern Mexico and mined amber in Chiapas (Bryant, 1983).

Description of male. Carapace (Fig. 8) with long, thin, simple epistome; setae 6:4:4:2:2 (18) (count assumes that the right sublateral seta of the ocular row is present, although it could not been seen), preocular setae much shorter than others ( $0.040 \mathrm{~mm}$, versus $0.092 \mathrm{~mm}$ for anteromedian seta and 0.129 $\mathrm{mm}$ for longest seta); anteromedian setae far apart (distance $0.058 \mathrm{~mm}$ ). Tergal setae 4?:4:4:6:7:7:8:8:2T2T:6:2T2T?:0; tactile setae of tergite XI $0.29 \mathrm{~mm}$ long, set on tubercles (Fig. 7). Pleural membrane granulostriate. Coxae difficult to study, coxal spines obscured; apical manducatory seta slightly longer than subapical seta, both simple. Posterior genital sternite with a long cleft, setae bordering cleft well spaced; sternite X with 9 long setae; XI 4T1T4 (length of tactile setae $0.17 \mathrm{~mm}$ ); XII with 2 long setae.

Chelicera (Fig. 8) longer than carapace; palm with 5 setae; fixed finger with 6 large teeth, movable finger with about 6 or 7 teeth which decrease in size proximally; rallum probably with 7 blades, arranged in a compact group (no 
recumbent blade observed), basal blade slightly shorter than others; serrula exterior with about 15 blades, serrula interior with about 13 blades, distal blades not much longer than others in either case; movable finger with spinneret small or absent; seta 0.42 from base, not reaching tip of finger.

Palp (Figs 1-5) with 3 enlarged setae on paraxial face of chela: distal seta at base of fixed finger, level with ist, length $0.153 \mathrm{~mm}$; median seta on distal part of palm, length $0.155 \mathrm{~mm}$; proximal seta slightly behind middle of palm, length $0.118 \mathrm{~mm} .27$ teeth on fixed finger and 27-29 teeth on movable finger, all teeth upright, spaced and in single file; distal tooth of fixed finger very small, not displaced (Fig. 5); basal teeth of movable finger slightly larger than others; no intercalary teeth on either finger. Trichobothria $i b$ and $i s b$ about one-third from base of palm; hairs of duplex trichobothria short $(0.033 \mathrm{~mm}$, without allowance for curvature). Several chemosensory setae present on dorsum of palm distad of $i b$ and $i s b$. Two proximal setae of paraxial row of movable finger slightly thickened, but much less so than enlarged setae of palm. Trichobothrium $s b$ roughly half-way between $b$ and st (0.46- 0.53 of distance from $b$ to $s t$ ). Fixed finger with 2 apical sensilla ( $a f$, Fig. 5); movable finger with a sensillum (probably $p_{2}$ ) midway between $s b$ and st (Fig. 4). Movable finger with an antiaxioventral row of at least 6 (probably 8) lanceolate chemosensory setae (Figs 2-3), extending along most of length of finger (less distinct proximally). Lamina defensor visible at tip of both fingers (Fig. 5).

Legs with normal segmentation, but strongly distorted; leg IV with short tactile setae on tibia (TS 0.38), basitarsus (TS 0.27) and telotarsus (TS 0.31); III with similar tactile setae; arolia shorter than claws and with lateral extremities slightly rounded in ventral view (Fig. 6).

Measurements. Body $1.14 \mathrm{~mm}$; carapace $0.32 \times 0.32$ (1.0); chelicera length ca 0.42 , movable finger 0.23 ; palp femur $0.58 \times 0.07(7.9)$, patella $0.21 \times 0.09(2.3)$, chela 0.82 $\times 0.10(8.1)$, palm $0.26(2.5)$, movable finger 0.55 (2.4).

Description of protonymph. Carapace (Fig. 9) without epistome on anterior margin (at most with a low, rounded projection in its place); setae 4:4:4:2:2 (16), preocular setae distinctly shorter than the others, anteromedian setae set far apart (distance $0.029 \mathrm{~mm}$ ). Tergal setae $2: 2: 2: 4: 4: 4: 4: 4: 1 \mathrm{TT} 1: 2 ?: 1 \mathrm{TT} 1: 0$; tactile setae of tergite XI set on strong tubercle (Fig. 11), hair length $0.121 \mathrm{~mm}$. Coxa I with blunt anterolateral process; coxal spines present at anteromedian angle of coxa II, but their exact form and number could not be determined. Sternites III-V probably with 2 setae each; VI-VIII each with 4 setae.

Chelicera (Figs 9-10) with 4 setae on palm; movable finger with a broad but low spinneret tubercle, seta gs absent; dentition reduced, only 2 small irregularities that might represent teeth seen on movable finger.

Palp (Fig. 12) chela with 3 spiniform setae arranged as in adult, lengths: distal 0.092 , medial 0.101 , proximal $0.063 \mathrm{~mm}$. Distal trichobothrium of fixed finger $\left(x_{1}\right)$ short (0.021 mm, not allowing for curvature), base bulbous (Fig.
13). Movable finger without thickened setae, but basal seta on paraxial side longer than others. No chemosensory setae observed on dorsum of palm. The condition of the specimen does not allow the presence or absence of lanceolate setae on the movable finger to be determined with certainty, but there seems to be one such seta just distad of trichobothrium $t$ and another just behind $t$.

Legs normal, tactile setae of tibia, basitarsus and telotarsus of leg IV quite short.

Measurements. Body $0.48 \mathrm{~mm}$; carapace $0.212 \times$ 0.215 (1.0); chelicera $0.188 \times 0.088$ (2.1), palm $0.099(1.1)$, movable finger $0.105(1.1)$; palp femur $0.254 \times 0.063(4.1)$, patella $0.094 \times 0.066(1.4)$, chela $0.364 \times 0.059(6.2)$, palm 0.129 (2.2), movable finger 0.232 (1.8). Leg I (lengths only) femur 0.099, patella 0.074, tarsus 0.155; leg IV (lengths only) tibia 0.138 , basitarsus 0.066 , telotarsus 0.139 .

Remarks. The attribution of this species to the extant genus Paraliochthonius is slightly problematic because it has trichobothrium $s b$ in a more basal position than usual and the form of the coxal spines could not be determined. However, the presence of three thickened setae on the chelal palm and the well-spaced anteromedian setae of the carapace are consistent with Paraliochthonius, even if they are not unique to this genus. An additional argument for assigning P. miomaya n. sp. to Paraliochthonius is that the bases of the tactile setae of tergite XI are raised on a dome-shaped base (Figs 7, 11). This modification, which had not been noted before, is also present in Paraliochthonius darwini Harvey, 2009, P. hoestlandti Vachon, 1960, P. singularis (Menozzi, 1924) and $P$. vachoni Harvey, 2009 (pers. obs.). The tactile setae are not raised in the species of Tyrannochthonius, Lagynochthonius Beier, 1951 and Ayyalonia Ćurčić, 2008 that I have examined.

The strong distortion of the holotype of $P$. miomaya gives it a rather caricatural appearance and hampers comparison with extant species. Based on the dentition of the chela and the form and arrangement of the thickened setae, P. miomaya most closely resembles $P$. johnstoni (Chamberlin, 1923) and P. mexicanus Muchmore, 1972, both from the Pacific coast of Mexico, P. litoralis Mahnert, 2014, from the Galapagos Islands (Ecuador), and P. quirosi Bedoya-Roqueme, 2015, from Colombia. It differs from them in the position of trichobothrium $s b$, which is closer to $s t$ than to $b$ in the extant species (although Lee (1979) illustrates a specimen of $P$. johnstoni in which $s b$ is only slightly more than halfway between them) and in the wider spacing of the two distal thickened setae, with the distalmost seta lying distad of trichobothrium ist (in the extant species it lies opposite or slightly proximad to ist). In addition, $P$. litoralis differs from $P$. miomaya in having the distal teeth of the movable chelal finger slightly retrorse.

The presence of thickened or lanceolate 'sensory' setae on the movable finger of certain Tyrannochthoniini was first noted by Mahnert (2011) in several species of Lagynochthonius and later observed in a species of Paraliochthonius (Mahnert, 2014). These setae are probably 
chemosensory or, perhaps, hygroreceptive. It is preferable to avoid the term 'sensory' because this could apply to any type of seta, including normal setae (which have a tactile sense). For convenience, the modified setae are therefore referred to as 'chemosensory setae' here, even though experimental evidence of their function is not yet available. The chemosensory setae on the movable finger of $P$. miomaya have the same form as those illustrated by Mahnert (2011: fig. 27), consisting of a hair shaft with a lamelliform extension on one side. The only differences are that, in P. miomaya, the lamella only extends for about half the length of the shaft and is directed distally relative to the axis of the finger.

The paratype of $P$. miomaya is the first fossil of an immature pseudoscorpion that can be correlated with its adult stage with a high degree of certainty, having been found in the same piece of amber and belonging to a genus whose modern species are not known to show sympatry. More importantly, it is the first protonymph known for any species of Paraliochthonius. The lack of records of protonymphs for extant Paraliochthonius species can probably be attributed to the habitats in which they are found (under stones on beaches and in caves), which are usually only sampled by hand-collecting, during which it is easy to overlook such tiny nymphs. The only other genus of Tyrannochthoniini in which free-living protonymphs have been found is Tyrannochthonius (e.g. Hoff, 1959). The absence of any records of protonymphs for the genus Lagynochthonius is surprising, but it remains to be seen whether this is due to inadequate sampling or their remaining in the brood nest until the moult to the deutonymph. It is noteworthy that the spiniform setae of the chelal palm are already differentiated in the protonymph of P. miomaya.

Extant Paraliochthonius are usually collected under stones in the intertidal zone of open beaches, but they do also occur in mangroves. Lee (1979) recorded a specimen of $P$. johnstoni from "under a rock near a mangrove plant on a sandy beach" in Baja California Sur and BedoyaRoqueme (2015) described P. quirosi from adults collected in a mangrove in Colombia. There is a published record of a "Paraliochthonius sp." from a Neotoma nest in the Mexican Altiplano (Villegas-Guzmán and Pérez, 2005), but no further details are available about this surprising find. The genus has a wide distribution, being found in Mexico, Florida, the Caribbean, Macaronesia, the Mediterranean, eastern Africa, Australasia and Japan (Harvey, 2009).

Genus Tyrannochthonius Chamberlin, 1929

\section{Tyrannochthonius sp.}

Figures 14-17, 33-34

Material examined. $1+$, in small $(5.5 \times 4.5 \times 2 \mathrm{~mm})$, clear, cuboid amber offcut, collected from Chiapas, Rio Totolapa Salado Village, in personal collection of D. Coty (TOT 004 1/3). The specimen is in an excellent state of preservation, with no obvious deformation, but some parts are obscured by bubbles.

Description. Carapace (Fig. 14) nearly quadrate, slightly constricted posteriorly; epistome reduced to a low boss; anterior eyes with well developed lens, posterior eyes reduced to spots; setae 4:4:4:2:2 (16), without preocular setae, anteromedian setae not particularly close to epistome, diverging in dorsal view.

Tergal setae 4:4:4:6:6:6:6:6:2T1T2:4:T2T:0. Pleural membrane papillostriate back to segment VIII, papillae gradually becoming sparser and disappearing by segment IX. Coxa I with long, thin process, which does not bear setae; palp coxa with 2 setae on manducatory process plus 3 setae (total 5); setae of leg coxae I 2, II 5, III 5, IV 5; coxa II (Fig. 15) with 4 relatively large, distally pinnate spines; intercoxal tubercle absent. Only 2 setae visible on anterior genital sternite, but others might be obscured by coxae IV; posterior genital sternite with 2 anterior and 6 posterior setae (total 8); setae of sternites IV-XI m6m?:m6m:m6m?: $\mathrm{m}$ ?m?:m7m:s7s:3T1T3:2T1T2:2.

Chelicera with 5 setae on palm, $d b$ directed upwards.

Palp chela (Figs 16-17) with 2 chemosensory setae on dorsum; fixed finger with 15 sharp, upright teeth, anterior 8 teeth alternating with single microdenticles; movable finger with 9 sharp, upright teeth, followed by about 4 or 5 rounded teeth, teeth 2-7 alternating with single microdenticles; trichobothria $i b$ and $i s b$ slightly behind middle of palm; trichobothrium $s b$ closer to $b$ than to $s t$ ( 0.37 of distance $b-$ $s t$ ); a raised spot sensillum (probably $p_{2}$ ) at 0.37 of distance from $s b$ to $s t$.

Leg IV with extensive granulation on anterior face of patella; telotarsus TS 0.15 .

Measurements. Body 1.0; carapace $c a 0.31 \times 0.28(c a$ 1.1); palp femur ca $0.35 \times 0.07$ ( ca 5.4), patella $0.13 \times 0.08$ (1.6), chela $0.51 \times 0.10(5.2)$, palm 0.19 (1.9), movable finger 0.33 (1.7). Leg IV telotarsus $0.34 \times 0.03$ (13.3).

Remarks. This species resembles T. floridensis Malcolm and Muchmore, 1985, from North America, but the latter is slightly larger and has a shorter process of coxa I that bears a seta. The single epigean species of Tyrannochthonius known from Mexico, T. volcanus Muchmore, 1977, also has the epistome reduced, but it differs from the fossil in having a lower number of setae on the anterior tergites, longer chelal fingers with a larger number of teeth and in being larger (Muchmore, 1977). Although the fossil appears to belong to an undescribed species, it is not named here because the only available specimen is currently in a private collection.

Family Atemnidae Kishida, 1929

Subfamily Atemninae Kishida, 1929

Genus Paratemnoides Harvey, 1991

Paratemnoides (?) sp.

Figures 18, 35

Material examined. 1 nymph (deutonymph?), in 

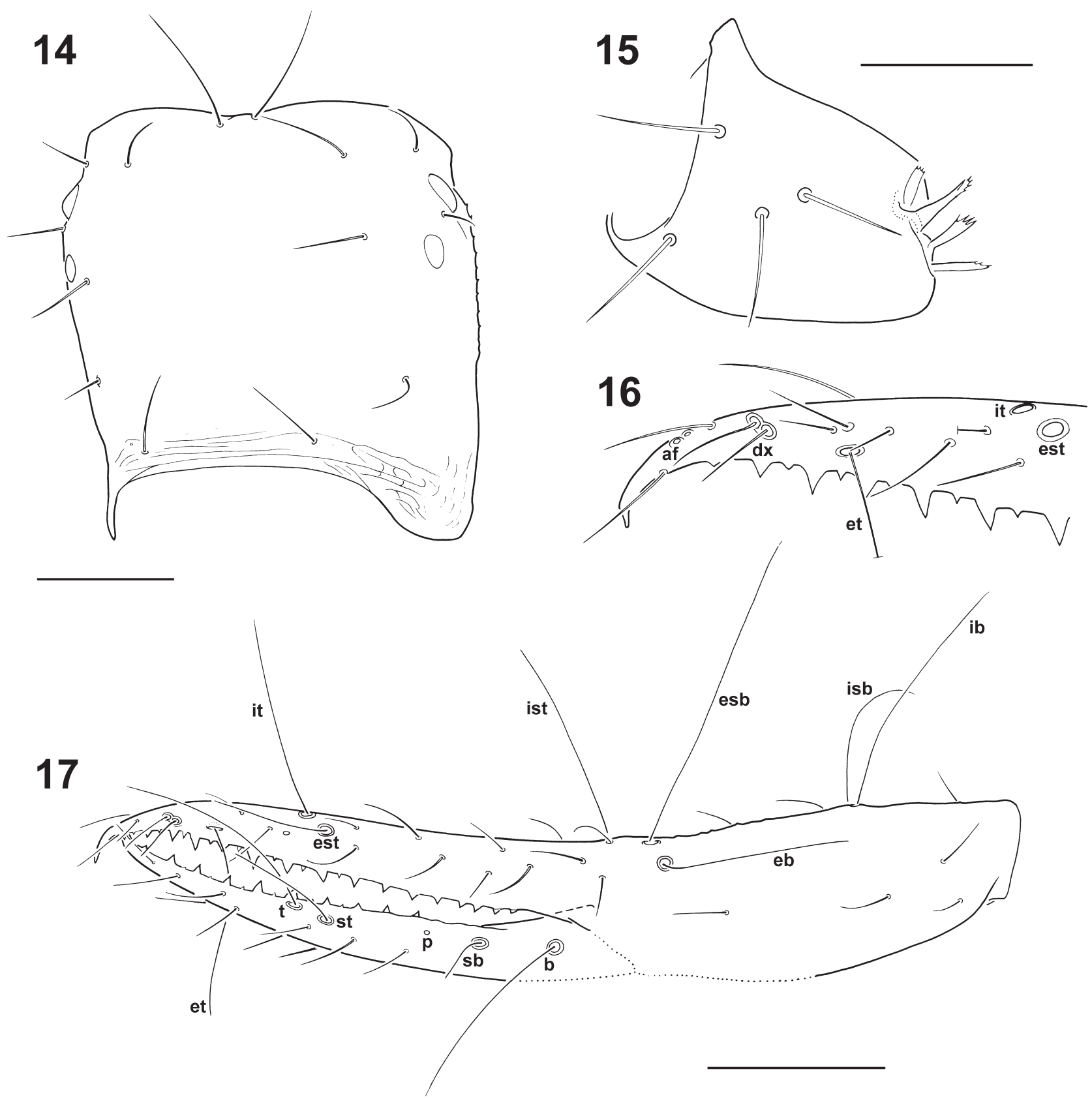

Figures 14-17. Tyrannochthonius sp. in amber from Totolapa. 14, Carapace, near-dorsal (slightly lateral, from right) view; 15, right coxa II, ventral view (form of first spine on left of drawing uncertain due to bubble; chaetotaxy probably incomplete); 16, tip of fixed finger of left chela, lateral view; 17, chela of left palp, lateral view (dotted parts reconstructed: obscured by bubble). Abbreviations are designations of individual trichobothria. Scale lines: $0.1 \mathrm{~mm}$ (Figures 14, 17), $0.05 \mathrm{~mm}$ (Figures 15, 16, to same scale).

large piece of amber $(50 \times 19 \times 18 \mathrm{~mm})$ from Simojovel (NMS G.2004.6.5). The piece also contains 14 small beetle larvae (all of same type) and some organic debris. The pseudoscorpion is darkened, strongly distorted by compression and lacks the left chela, could only be examined superficially due to a piece of debris in its vicinity and the large size of the amber; further preparation was not attempted because it would probably have destroyed one or more of the insect larvae, which have yet to be studied.
Description. Sclerotized parts without obvious granulation. Setae generally long, appearing simple at low magnification. Numerous tactile setae on posterior segments of opisthosoma. Palp (Fig. 18) with long and apparently simple setae (probably with small denticles, but specimen could not be examined at sufficient magnification to determine this), chelal palm with tactile setae $M_{1}$ and $M_{2}$ near base and $\mathrm{M}_{3}$ dorsally near middle. Leg IV with a long $(0.21 \mathrm{~mm})$ tactile seta close to the base of the segment (TS 


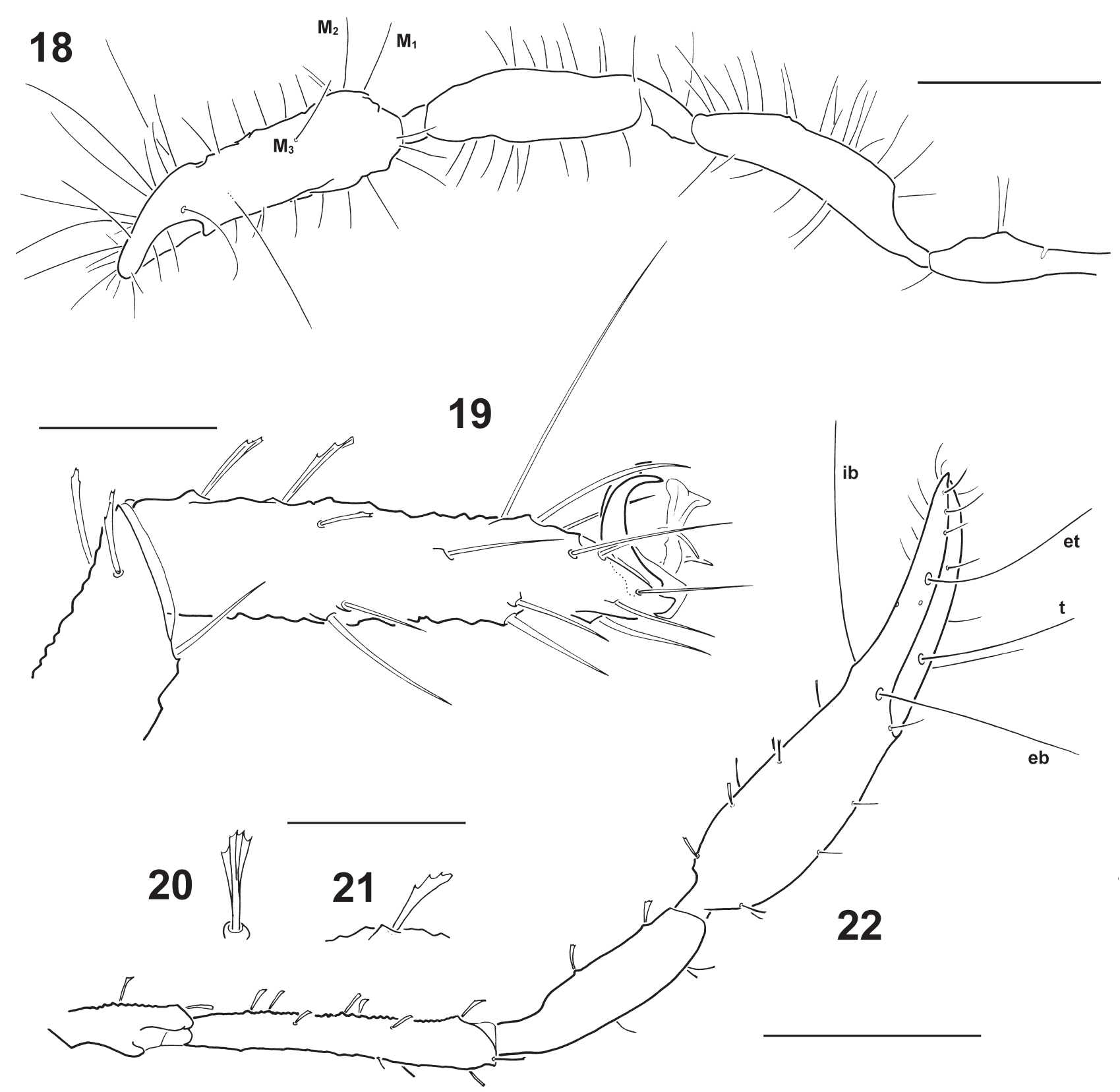

Figures 18-22. Atemnidae and Cheliferidae in amber from Simojovel. 18, Paratemnoides (?) sp., right palp, dorsal view (chela inclined upwards, fingers strongly foreshortened); 19, cheliferid protonymph, distal part (end of tibia, tarsus and apotele) of left leg IV, lateral view; 20, cheliferid protonymph, distal seta on anterior margin of left palp trochanter (seen face-on); 21, cheliferid protonymph, basal seta on anterior margin of right palp femur (seen in side view); 22, cheliferid protonymph, right palp in near-dorsal view. Abbreviations: $\mathrm{M}_{1-3}$, tactile setae of chelal palm; other abbreviations are designations of individual trichobothria. Scale lines: $0.3 \mathrm{~mm}$ (Figure 18); $0.2 \mathrm{~mm}$ (fig. 22); $0.05 \mathrm{~mm}$ (Figures 19-21).

ratio $c a$ 0.1). Tibia of leg IV with a short tactile seta near middle. Leg claws simple.

Measurements. Body 1.6. Carapace length $\mathrm{ca} 0.57$. Palp femur $0.42 \times 0.09(<4.4)$, patella $0.43 \times 0.12(<3.6)$, chela $^{+} 0.89 \times 0.16(<5.7)$, palm $^{+} 0.63(<4.1)$, movable finger $0.39\left(0.62 \times\right.$ palm $\left.^{+}\right)$.

Remarks. This specimen is difficult to identify in its present state, but the basal position of the tactile seta of tarsus IV, the long and superficially simple setae, the absence of obvious granulation and the arrangement of the tactile setae of the palp suggest that it is a member of the Atemninae (Atemnidae). In particular, the tactile seta of the tarsus of leg IV is the basalmost seta on the dorsal face, whereas in chernetids there is usually an ordinary dorsal seta proximad of the tactile seta. Given that Paratemnoides Harvey, 1991 is the only genus of Atemnidae known from modern Mexico and Central America, the fossil is tentatively assigned to this genus. 
There are relatively few fossils known for Atemnidae. Beier (1955) described the genus Progonatemnus Beier, 1955 from Baltic amber, but its attribution to this family is questionable. Subfossil Atemninae have been reported from Madagascan and Colombian copals, the latter being identified as Paratemnoides nidificator (Balzan, 1888) by Judson (2010).

Family Cheliferidae Risso, 1827

Subfamily Cheliferinae Risso, 1827

Tribe Cheliferini Risso, 1827

Gen. sp. indet.

Figures 19-22, 36

Material examined. 1 protonymph, in drop-shaped cabochon $(23 \times 11 \times 7 \mathrm{~mm}$ before additional preparation $)$ of clear, yellow, amber with about 7 flow lines, from Simojovel, don. Ma. del Carmen Sánchez Gálves, 2010 (SMF Be 2510).

Description. Carapace, palps and legs with dense, even granulation. Cuticle fairly thick. Setae short and clavate on dorsal surfaces (Figs 20-21), including tergites. Carapace with anterior furrow distinct, posterior furrow weak; eyes with lens; very few setae observed, situated anteriorly and posteriorly. Tergal setae moderately clavate; XI without tactile setae. Sternal setae simple and much longer than those of tergites; sternites X and XI each with a pair of short, submedian tactile setae. Opisthosoma without pleural setae.

Cheliceral palm probably with 4 setae, of which $b$ is denticulate; movable finger without seta; spinneret with 3 apical rami arranged in ventral file.

Palp (Fig. 22) granulate (including coxa), except on fingers; paraxial setae of femur and patella inserted near base of strong tubercles. Chelal fingers each with about 22 contiguous teeth; no accessory teeth; venedens equally developed on fixed and movable fingers. Movable finger with two short tactile seta ventrolaterally, $\mathrm{T}_{1} 0.083 \mathrm{~mm}$ long and 0.85 from base, $\mathrm{T}_{2} 0.110 \mathrm{~mm}$ long and 0.29 from base, just behind trichobothrium $t$.

Anterior legs with femur wider than patella, joint between them oblique. Tactile seta of leg IV long $(0.90$ $\mathrm{mm}$ ), situated 0.69 from base (Fig. 19); leg III without tactile seta. Subterminal setae simple, posterior seta thicker than anterior seta on all legs. Leg claws simple. Arolia simple, fan-shaped and slightly shorter than claws.

Measurements. Body 0.71. Palp femur $0.269 \times 0.055$ (4.9), patella $0.228 \times 0.063(3.6)$, chela $0.486 \times 0.090(5.4)$, palm $^{+} 0.285$ (3.2), palm 0.247 (2.7), movable finger 0.232 $\left(0.81 \times\right.$ palm $\left.^{+}\right)$. Leg IV femoropatella $0.213 \times 0.055(3.9)$, tibia $0.173 \times 0.035(4.9)$, tarsus $0.153 \times 0.033(4.6)$.

Remarks. The assignment of this specimen to the Cheliferidae is based on the equal development of the venedens on each chelal finger, the presence of lensed eyes and its general appearance. Comparing the protonymph with the cheliferid genera currently known from Mexico, the combination of having tuberculate clavate setae on palps, the tactile seta of tarsus IV in a distal position and simple subterminal setae on the legs suggests that it might belong to either Hysterochelifer Chamberlin, 1932 or Levichelifer Hoff, 1946. Unfortunately, nymphs have not been described for Levichelifer or the great majority of Hysterochelifer species, so it cannot be decided whether the fossil might belong to one genus or the other.

Family Chernetidae Menge, 1855

Genus Byrsochernes Beier, 1959

Byrsochernes Beier, 1959: 206.

Mayachernes Riquelme, Piedra-Jiménez and CórdovaTabares, 2014a: 903-904, 907. New synonym.

Remarks. The monotypic genus Mayachernes Riquelme, Piedra-Jiménez and Córdova-Tabares, 2014 was erected for Mayachernes maatiatus Riquelme, Piedra-Jiménez and Córdova-Tabares, 2014, which was described from an adult male in amber from Simojovel. Riquelme et al. (2014a) compared Mayachernes to members of the "Lustrochernes clade (sensu Beier, 1932)", which they considered to comprise the genera Americhernes Muchmore, 1976, Cordylochernes Beier, 1932, Gomphochernes Beier, 1932, Incachernes Beier, 1933, Lamprochernes Tömösváry, 1882, Mesochernes Beier, 1932 and Odontochernes Beier, 1932 (the omission of Lustrochernes from their list was evidently an oversight). This grouping corresponds to the subfamily Lamprochernetinae as originally diagnosed by Beier, (1932a, 1932b). However, it has long been recognized that the subfamilies and tribes of Beier's (1932a) classification of the Chernetidae are artificial groups (Muchmore, 1972). Legg (1987) proposed modified definitions of Lamprochernetinae and Chernetinae, based on the form of the spermathecae, but only applied these to European genera. Harvey $(1994,1995)$ adopted this proposal and extended it to all genera. Because the form of the spermatheca is unknown for Mayachernes, it is insufficient to compare this genus solely with members of the Lamprochernetinae.

When the comparison is extended to the other genera of Chernetidae, it becomes evident that Mayachernes is similar to the genus Byrsochernes Beier, 1959, which is known from two extant species: B. ecuadoricus Beier, 1959, found in Ecuador (Beier, 1959) and Mexico (Beier, 1976a), and $B$. caribicus Beier, 1976, found in the Dominican Republic (Beier, 1976b) and the Cayman Islands (Hounsome, 1980). The only apparent obstacles to placing M. maatiatus in Byrsochernes are the arrangement of the trichobothria and the presence of a tactile seta on the tibia of leg IV.

The positions of the trichobothria illustrated by Riquelme et al. (2014a) are probably erroneous in part: although the trichobothria are only barely visible on the published photographs (Riquelme et al., 2014a: figs 3e-g), it can be seen that some of them are not drawn in their correct positions by Riquelme et al. (2014a: figs 5g-h). Based on the published photographs (digitally modified 
to enhance contrast), a reinterpretation of the arrangement of the trichobothria of $B$. maatiatus $\mathrm{n}$. comb. is given in Fig. 23. The differences from the original interpretation (Fig. 24) are that trichobothria $e t, b, s b$ and st occupy more proximal positions. The positions of trichobothria $b$ and $s b$ are uncertain because they are less clear the original photographs, but it seems unlikely that the arrangement shown by Riquelme et al. (2014a: figs 3g-h) is correct: an equidistant spacing of $b, s b$ and $s t$ would be very unusual for Chernetidae, in which $s b$ is usually closer to $b$ than to $s t$ (as, indeed, it is in most Cheliferoidea). If correctly interpreted here, the trichobothriotaxy of B. maatiatus $\mathrm{n}$. comb. is similar to those illustrated for B. ecuadoricus and B. caribicus by Beier $(1959,1976 \mathrm{~b})$, with the position of $s b$ being intermediate between them [Beier (1976b) described $s t$ as approaching $s b$, but his figure shows it to be only slightly closer to $s b$ than to $s t]$.

The presence or absence of a tactile seta on the tibia of leg IV can be quite subjective when it is reduced in size, as in genera like Byrsochernes that were difficult to place in one or other of the subfamilies as originally defined by Beier (1932a, 1932b). Beier (1959) originally attributed Byrsochernes to the Lamprochernetinae, but later (Beier, 1976b) transferred it to the Chernetinae because of the absence of a tactile seta on the tibia of leg IV. Beier (1959) did not indicate whether or not this was present in B. ecuadoricus, although the fact that he placed it in the Lamprochernetinae would imply that it is present. I suspect that the tactile seta is present but small in both of the extant species of Byrsochernes.

In the absence of any convincing differences, it is concluded that Mayachernes is a junior subjective synonym of Byrsochernes.

\section{Byrsochernes maatiatus (Riquelme, Piedra-Jiménez and Córdova-Tabares, 2014) n. comb.} Figures 23-24

Mayachernes maatiatus Riquelme, Piedra-Jiménez and Córdova-Tabares, 2014a: 904-907, figs 2-4.

Remarks. No material of this species has been examined during the present study. The description provided by Riquelme et al. (2014a) is generally good and well illustrated, although as discussed above, the interpretation of the trichobothriotaxy probably includes errors. The unusual chaetotaxy they illustrate for the carapace (Riquelme et al., 2014a: fig. 4a), with just two median rows of setae, appears to be the result of a reconstruction: judging from their photographs (Riquelme et al., 2014a: figs. 3a, 3h) the carapace was observed obliquely and the setae shown in the reconstructed dorsal view are those that were most prominent because they were situated on the apparent margin seen in dorsolateral view. The chelicera is described as having four setae on the palm, with es being absent, but it seems more likely that the latter was overlooked, since when there are only four setae it is usually $s b$ that is missing.

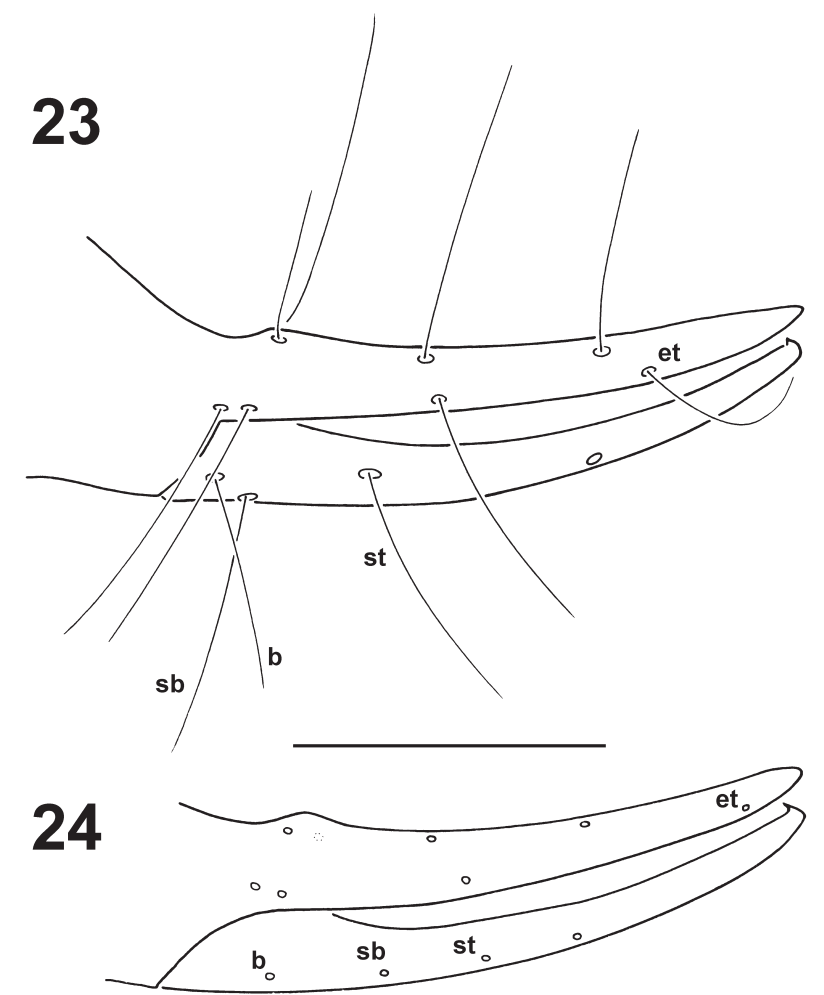

Figures 23-24. Byrsochernes maatiatus (Riquelme, Piedra-Jiménez and Córdova-Tabares, 2014), arrangement of trichobothria on right chelal fingers of holotype: 23 , new interpretation based on photographs published by Riquelme et al. (2014a); 24, previous interpretation (redrawn from Riquelme et al., 2014a), hairs of trichobothria not shown. Abbreviations are designations of individual trichobothria. Scale line $0.3 \mathrm{~mm}$.

Byrsochernes maatiatus $\mathrm{n}$. comb. can be separated from the extant species by its smaller size; for example the length of the palp femur is $0.90-0.95$ in B. caribicus and $1.05 \mathrm{~mm}$ in B. ecuadoricus, as opposed to $0.63 \mathrm{~mm}$ in B. maatiatus. The tactile seta of leg IV also seems to be slightly more basal in B. maatiatus, with a TS ratio of 0.23 , whereas the extant species are described as having this seta about $1 / 3$ from the base. Trichobothrium $s t$ has a less basal position in B. maatiatus than in B. ecuadoricus, which is more like B. caribicus in this respect (though it is possible that some variation occurs).

Genus Lustrochernes Beier, 1932 (?)

\section{Lustrochernes (?) sp. 1}

Figures 25-30, 37-38

Pseudoskorpion: Solórzano Kraemer and Rust, 2006: 337, unnumbered photograph (p. 339, upper left).

Pseudoscorpionida: Solórzano Kraemer, 2007: 7, 127; Solórzano Kraemer and Stebner, 2013: 29, fig. 2 [middle].

Material examined. 1 deutonymph, in prepared cuboid of amber $(5 \times 5 \times 3 \mathrm{~mm})($ SMNS Mx-258). 1 protonymph in prepared cuboid of amber $(4 \times 3 \times 1.6 \mathrm{~mm})$ from Simojovel, 


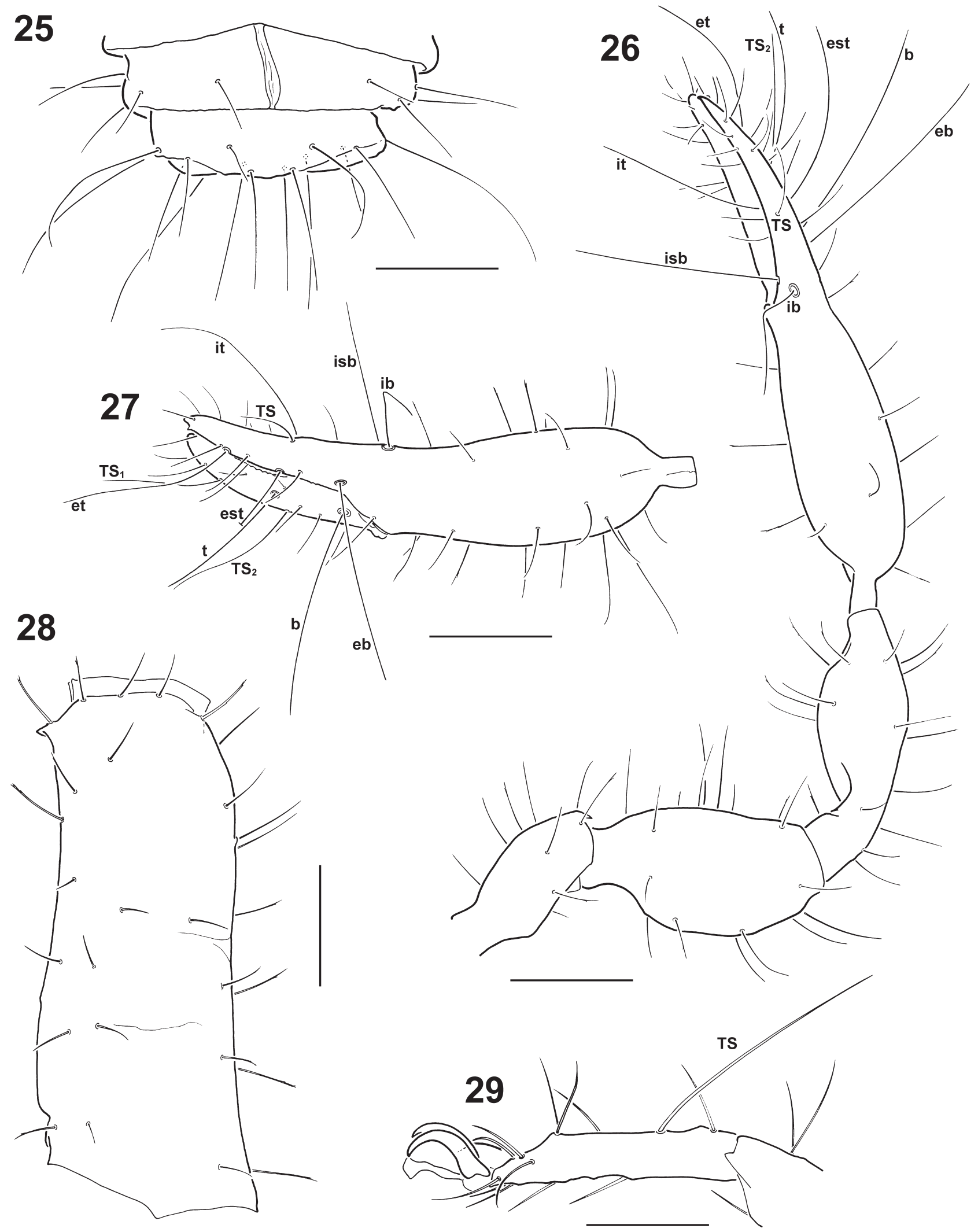

Figures 25-29, Lustrochernes (?) sp. 1, deutonymph (unless otherwise noted), 25, end of opisthosoma (tergites X and XI), dorsal view; 26, right palp, near-dorsal view; 27, left chela, dorsolateral view; 28, carapace, dorsolateral view (left side higher); 29, distal part (end of tibia, tarsus and apotele) of right leg IV, lateral view. Abbreviations: TS, $\mathrm{TS}_{1-2}$, tactile setae; other abbreviations are designations of individual trichobothria. Scale lines $0.1 \mathrm{~mm}$. 


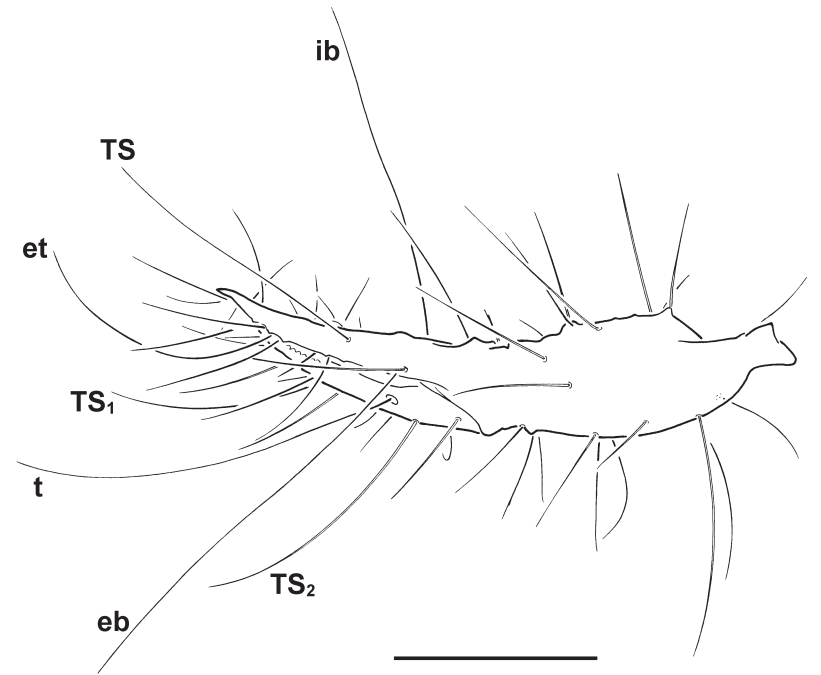

Figure 30. Lustrochernes (?) sp. 1, protonymph, left chela, antiaxiodorsal view. Abbreviations: TS, tactile seta of fixed finger; $\mathrm{TS}_{1-2}$, tactile setae of movable finger. Scale line $0.1 \mathrm{~mm}$.

embedded in synthetic resin (SMNS Mx-388.4). According to Solórzano Kraemer (2007: 130), the amber piece from which Mx-388.4 was cut also contained a ponerine ant and a cecidomyiid fly.

Description of deutonymph (Mx-258). The unusual appearance of this specimen (Fig. 37) can be attributed to distortion during fossilization, similar to that observed in certain fossils in Burmese amber (Judson, 2000). The patellae and chelae of the palps are unnaturally thinned and the carapace is much more elongate than would be expected in a chernetid. Vestitural setae long, weakly denticulate near tips ( 2 or 3 denticles). Sclerotized parts without strong granulation, smooth or nearly so (possibly with sparse granules on palp femur). Carapace (Fig. 28) without true furrows, but there seems to be a darker transverse band about 0.5 from base; eyes not visible; setae long and sparse, chaetotaxy 6:6:4:4:4:4 (32). Tergites I-X divided, separated by wide, longitudinally plicate membranes, half tergites with 1 discal, 3 posterior and 1 lateral seta; posterior segments (Fig. 25) with long tactile setae. Pleural membrane plicate. Chelicera with 5 setae on palm, $s b$ and $b$ weakly denticulate; galeal seta not reaching to tip of spinneret; spinneret long (unnaturally stretched), with three short ram (2 apical, 1 subapical). Palp (Figs 26-27) appearing smooth, but some granulation might be present paraxially on trochanter and disto-antiaxially on femur (cuticle irregular); palm clearly smooth. Femur strongly pedicellate and robust. Chela with normal, contiguous teeth, accessory teeth not observed. Only movable finger with well developed venedens. Trichobothrium $e b$ distad of $i b$, trichobothrium it opposite est, about halfway along finger. Fixed finger with a dorsal tactile seta near middle; movable finger with two tactile setae, similar in length to trichobothria (Fig. 27: $\mathrm{TS}_{1}, \mathrm{TS}_{2}$ ). Legs short and robust. Tarsus IV (Fig. 29) with long tactile seta (length greater than that of tarsus) proximad of middle of segment (TS ratio 0.30). Arolia of legs with normal form, about as long as claws. Claws and subterminal setae simple.

Measurements. Body 1.1. Carapace length 0.46. Palp femur $0.24 \times 0.11(2.1)$, patella $0.26 \times 0.08$ (3.2), chela 0.47 x 0.10 (4.7), hand 0.29 (2.9), movable finger 0.28 (0.94).

Description of protonymph (Mx-388.4). Cuticle smooth, setae long and weakly denticulate. Carapace without evident furrows. Posterior segments of opisthosoma with long tactile setae. Pleural membrane plicate. Cheliceral serrula exterior with 11 blades; spinneret long (stretched), with 2 apical and 1 subapical rami; movable finger without seta. Palp femur and patella without recognizable tactile setae (all setae long); chela (Fig. 30) with 2 tactile setae at base of palm; 1 tactile seta dorsally on fixed finger; movable finger with 2 ventral tactile setae, 1 proximad of trichobothrium $t$ and the other just distad of middle; fingers each with about 13 contiguous teeth, mostly broad and truncate; no accessory teeth visible. Leg IV tibia without obvious tactile seta (all setae long); tarsus with long ( 0.125 $\mathrm{mm}$ ) tactile seta $0.24-0.25$ from base. Leg claws simple, slightly longer than arolium, latter normal, fan-shaped.

Measurements. Body 0.65. Carapace length $\mathrm{ca} 0.26$. Palp patella $0.171 \times 0.042(4.1)$, chela ${ }^{+} 0.367 \times$ depth 0.049 (7.4), palm 0.213 (1/d 4.3), palm 0.180 (1/d 3.7), movable finger $0.155(0.86 \times \text { palm })^{-}$.

Remarks. It is difficult to identify immatures of Chernetidae even in modern representatives. However, the combination of long, weakly dentate setae, largely smooth cuticle, trichobothrium it midway along finger and opposite est, tactile seta of tarsus IV in basal third, simple leg claws is consistent with the Lustrochernes-MesochernesCordylochernes complex of genera, members of which are very common in Central America. Based on the size of the specimens, it would be reasonable to attribute them to either Lustrochernes or Mesochernes. The choice between them is rather arbitrary, but it is probably of little consequence because it seems likely that these genera will eventually be synonymized. I have chosen to tentatively attribute them to Lustrochernes because this genus is more speciose and widely distributed, with modern species being recorded from Mexico (unlike Mesochernes).

\section{Lustrochernes (?) sp. 2}

Figure 39

Pseudoscorpion: Ross and Sheridan, 2013: fig. 2.

Material examined. 1 tritonymph, in large $(34 \times 22$ $\times 21 \mathrm{~mm}$ ), wedge-shaped piece of Mexican amber (exact source not indicated, but presumably Simojovel), NMS G.2011.31.2.

This specimen was illustrated by Ross and Sheridan (2013) as a "pseudoscorpion holding an ant". Although the ant is adjacent to the right chela of the pseudoscorpion (Figure 39), it is not actually held by the fingers, which are closed. Other inclusions in the piece are a female 

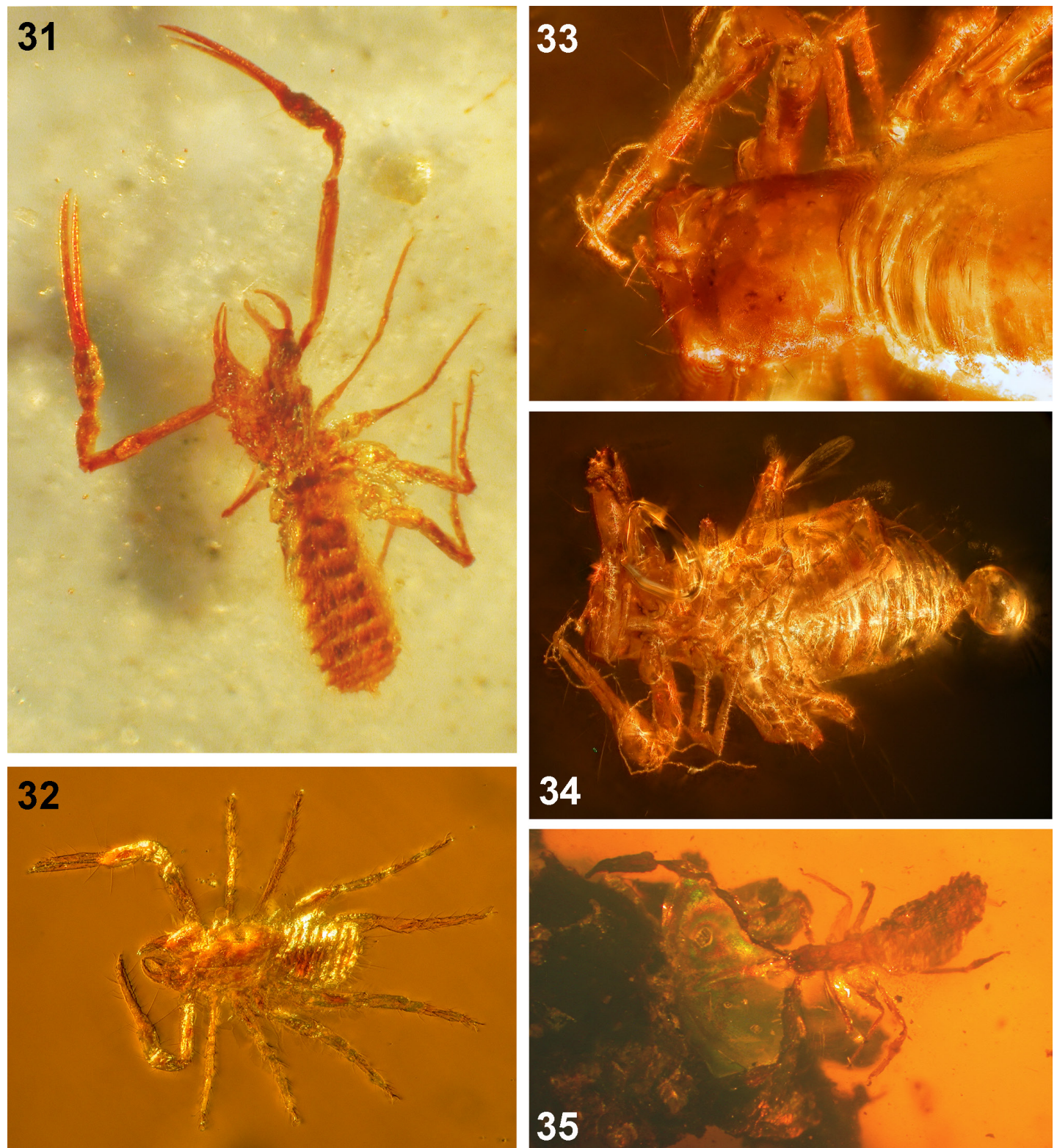

Figures 31-35. Chthoniidae and Atemnidae in Mexican amber. 31, holotype male of Paraliochthonius miomaya n. sp. in amber from Simojovel, dorsal view; 32, paratype protonymph of Paraliochthonius miomaya n. sp. in amber from Simojovel, dorsal view; 33, Tyrannochthonius sp. in amber from Totolapa, carapace, anterior tergites and right palp; 34, Tyrannochthonius sp. in amber from Totolapa, ventral view; 35, Paratemnoides (?) sp. in amber from Simojovel, dorsal view.

scale insect (Coccoidea) and two small, adult beetles. The pseudoscorpion is in reasonable condition, but shows clear signs of distortion. There are decompression haloes around the femur, patella and chelal palm of both palps, as well as around the body.

Description. Vestitural setae long and superficially simple. Sclerotized parts without obvious granulation, but the cuticle is irregular due to compression. Carapace without obvious furrow. Tergites and sternites of segments X-XI with tactile setae (probably 2 pairs on each) Chelicera with about 15 blades in serrula exterior, other details not resolved. Palp probably mostly smooth, but irregularities on the paraxial faces of the femur and patella might be granules; femur with 2 tactile setae on posterior margin, one situated 0.68 from base and the other near the distal end; no tactile setae evident on patella; chelal palm with several tactile seta towards base, but these are only slightly longer than other setae. Chelal fingers not gaping when closed; teeth small, contiguous, estimated to number about 30 ; fixed finger with about 5 paraxial accessory teeth. Leg IV with a short tactile seta distally on patella; a short tactile seta on the tibia (TS $0.52-0.53$ ) and a slightly elongated dorsal seta distally; tarsus with a longer tactile seta situated $0.24-0.28$ from base. Leg III with similar arrangements of tactile setae, but those of tibia (TS 0.68) and tarsus (TS 0.32) slightly further from base. Leg claws simple, about the same length as arolia. 

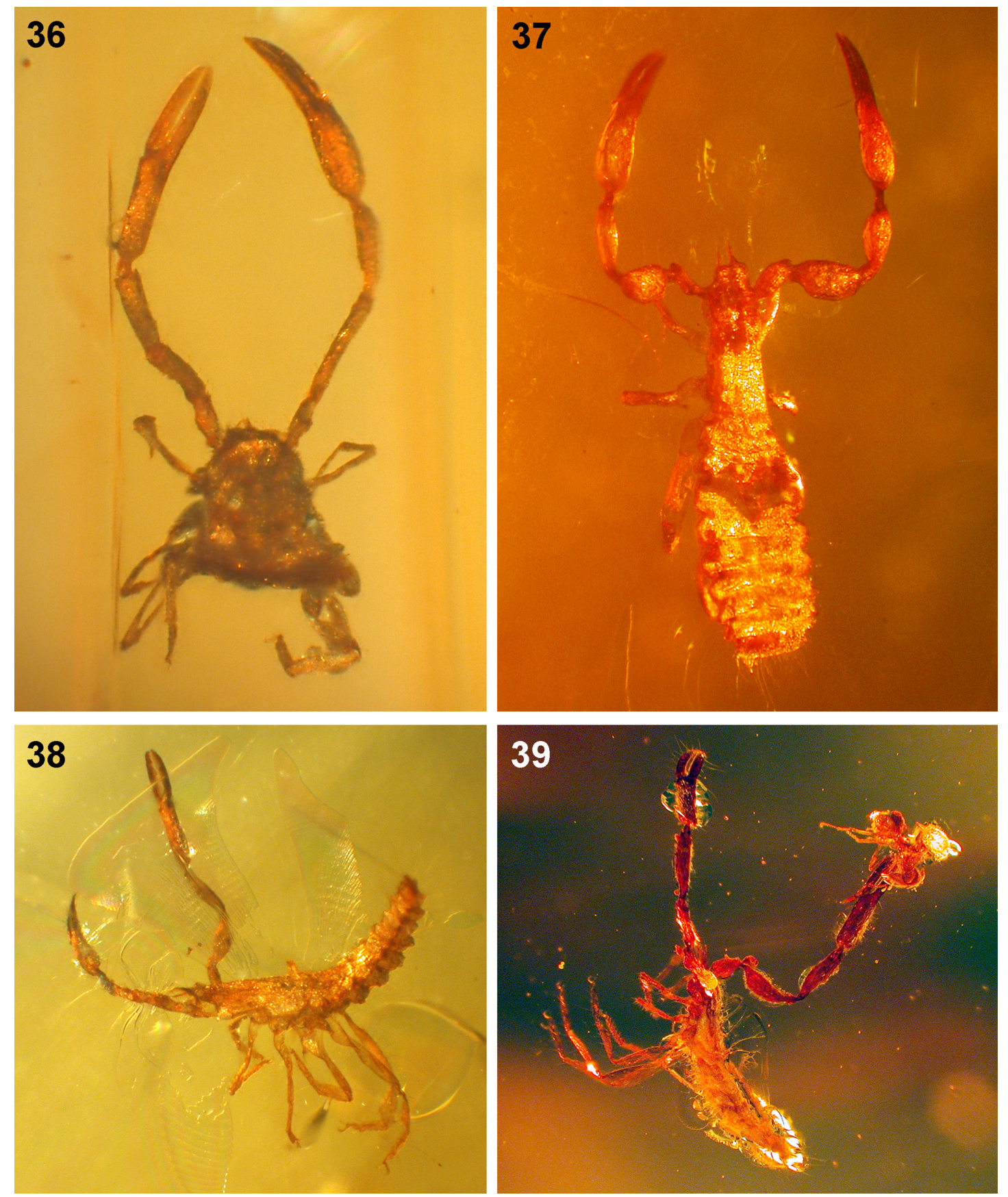

Figures 36-39, Cheliferoidea in amber from Simojovel. 36, Cheliferidae, protonymph, dorsal view (opisthosoma directed upwards and strongly foreshortened); 37, Lustrochernes sp. 1, deutonymph, dorsal view; 38, Lustrochernes sp. 1, protonymph, lateral view; 39, Lustrochernes sp. 2, tritonymph, lateral view (note small ant worker next to right chela).

Measurements. Body 2.0. Palp femur $0.68 \times 0.17(4.1)$, patella $0.66 \times$ depth $0.15(4.3)$, chela ${ }^{+} 0.98$, depth $0.21(1 / \mathrm{d}$ 4.7), palm 0.57 (1/d 2.7), palm- 0.45 (1/d 2.2), movable finger $0.47\left(0.83 \times\right.$ palm ${ }^{+}, 1.05 \times$ palm $)$. Leg IV femur 0.19 $\times 0.09(2.0)$, patella $0.43 \times 0.11(3.8)$, femoropatella 0.66 (7.0), tibia ca $0.46 \times 0.06(7.5)$, tarsus $0.31 \times 0.06(5.0)$.

Remarks. This specimen is generally similar to the nymphs attributed to Lustrochernes sp. 1 above and is tentatively assigned to Lustrochernes for the same reasons.
However, the difference in size between the deutonymph and the tritonymph seem too large to be attributed solely to the growth between these stages in a single species.

\section{Gen. sp. indet.}

Chernetidae, Schawaller, 1982: 3-6, figs 2-6.

Remarks. None of the fossils examined here can be considered conspecific with the chernetid protonymph 
described from Mexican amber by Schawaller (1982). Although the latter seems similar to Byrsochernes maatiatus in a number of respects, it differs from that species in having the tactile seta of tarsus IV near its middle (as opposed to near the base in $B$. maatiatus). When the tactile seta is inserted in the middle of the tarsus in the protonymphs of other chernetids, the TS ratio increases during ontogeny (Gabbutt, 1972), such that the adult of Schawaller's species would be expected to have the tactile seta distinctly distad of the middle.

One probable error concerning Schawaller's (1982) description of the protonymph is worth noting. Schawaller stated that the 'usual' seta $(g l)$ was present on the movable finger of the chelicera, but this would be highly exceptional because this seta only appears in the deutonymph in all species where its development has been observed. It is therefore likely that Schawaller's observation of this seta was mistaken.

\section{Extant pseudoscorpions from mangrove and Hymenaea trees in Chiapas}

The pseudoscorpions of mangroves have rarely been studied. Snodgrass (in Banks and Snodgrass, 1902) recorded Atemnus insularis Banks, 1902 from a mangrove swamp on the island of Albermerle, in the Galapagos. Muchmore $(1976,1979)$ and Muchmore and Alteri (1974) reported on the pseudoscorpions from mangroves of the Florida Keys, mostly collected during the famous island colonization experiments of Simberloff and Wilson (1969). Muchmore $(1981,1997)$ collected pseudoscorpions from mangrove trees on the Virgin Islands. Harvey (1991b: 292) recorded the littoral species Parahya submersa from a mangrove on Sulawesi. Mahnert (2014) and Baert and Mahnert (2015) recorded species of the genera Pseudochthonius Balzan, 1892, Lechytia Balzan, 1891, Ideoblothrus Balzan, 1892, Aphelolpium Hoff, 1964, Stenolpium Beier, 1955, Serianus Chamberlin, 1930, Neocheiridium Beier, 1932 and Parachernes Chamberlin, 1931 from mangroves (mostly in litter) of the Galapagos Islands. Records of the littoral genus Paraliochthonius from mangroves in Mexico (Lee, 1979) and Colombia (Bedoya-Roqueme, 2015) have already been mentioned above. None of the species concerned is restricted to this habitat, with the possible exception of Americhernes reductus Muchmore, 1976, described from mangroves in Florida and Belize, which Muchmore (1976) suggested was probably widespread in this habitat in the Caribbean.

As part of a project to compare the fauna of Simojovel amber with that of modern mangrove habitats in Chiapas, extant arthropods have been sampled at Coquitos and La Cadena (Solórzano Kraemer and Stebner, 2013; Solórzano Kraemer et al., 2015). The extant pseudoscorpions obtained during that study are listed below. The pseudoscorpion fauna of Chiapas has recently been summarized by Córdova-Tabares and Villegas-Guzmán (2013), who listed 32 species from the state. One of the species identified here (Americhernes oblongus) is new to Mexico and one (Parachernes insuetus) is new to Chiapas State. The genus Dolichowithius is recorded for the first time in Mexico, but the identity of the species concerned is uncertain. A further species of Withiidae cannot be placed with certainty, although it shows similarity to the genus Balanowithius Beier, 1959.

\subsection{Systematic list}

Superfamily Chthonioidea Daday, 1889

Family Tridenchthoniidae Balzan, 1891

Subfamily Tridenchthoniinae Balzan, 1891

Genus Tridenchthonius Balzan, 1891

\section{Tridenchthonius mexicanus Chamberlin and Chamberlin, 1945}

Material examined. $1+$ (carrying 10 small eggs), Cadena, open eclector, 26.4.2011 (CNAN-UNAM).

Remarks. The female from Cadena agrees in most respects with the description of T. mexicanus, but is has a slightly lower number of chelal teeth (58 on fixed finger, 48 on movable finger), slightly more robust palp segments (femur 3.8, chela 4.5 times longer than broad, movable finger 1.6 times longer than palm). These differences can be attributed to intraspecific variation. The number of setae on the posterior margin of the carapace and the ratio of the movable finger to palm length of the chela, which were used by Chamberlin and Chamberlin (1945) as key characters for separating T. mexicanus and T. juxtlahuaca, are not reliable. In their key to the species of the genus, Chamberlin and Chamberlin (1945) indicated that there were only six setae on the posterior margin in T. mexicanus, but this is slightly misleading because they note in the description of this species that seven were sometimes observed. Mahnert (1985a) also found 7 setae in specimens from Manaus, Brazil. Given that the setae are arranged asymmetrically in such cases, it is likely that some individuals will be found with eight setae, giving an expected range of 6-8. According to Chamberlin and Chamberlin (1945), the female of $T$. mexicanus has sternites IV-VII divided, but this is not the case in the female examined here and might be an error or a reflection of the different methods of preparation.

This species was described from the Mexican states of Veracruz and Chiapas (Chamberlin and Chamberlin, 1945) and later recorded from Trinidad (Hoff, 1946a), Costa Rica (Beier, 1976a) and Brazil (Mahnert, 1985a, 1985b). It is known to be phoretic on wood-boring passilid beetles (Reyes-Castillo and Hendrichs, 1975; Aguiar and Bührnheim, 1998). 
Superfamily Cheliferoidea Risso, 1827

Family Atemnidae Kishida, 1929

Subfamily Atemninae Kishida, 1929

Genus Paratemnoides Harvey, 1991

\section{Paratemnoides nidificator (Balzan, 1888)}

Atemnus nidificator Balzan, 1888: text (1 p., unpaginated) accompanying third (unnumbered) plate.

Chelifer (Atemnus) nidificator minor Balzan, 1891: 510-511 (synonymized by Klausen, 2005: 646-647).

Atemnus elongatus Banks, 1895: 10. New subjective synonymy.

Atemnus floridanus Tullgren, 1900: 153-155, fig 1. New subjective synonymy (previously synonymized with A. elongatus Banks, 1895 by Banks, 1904: 141).

Atemnus insularis Banks in Banks and Snodgrass, 1902: 54 (table), 68-69, 80, pl. II, fig. 11 (synonymized by Mahnert, 2014: 185).

Paratemnus guianensis di Caporiacco, 1947: 21 (synonymized by Mahnert, 2013: 19).

Trinidatemnus separatus van den Tooren, 2008: 435439 , figs $6-8$. New subjective synonymy.

See Harvey (1991a, 2013) for complete citations.

Material examined. 1 , , Cadena, pitfall trap, 23.4.2011 (CNAN-UNAM); $1 \hat{0}, 1$ ㅇ (both in poor condition), Chiapas, Cadena, sticky trap-yellow, 16-26.4.2011, leg. Solórzano Kraemer (CNAN-UNAM); 3 Tn (all exuviae?), Cadena, eclector, 20.4.2011, leg. Solórzano Kraemer (CNAN-UNAM; 1 Tn MNHN); 1 Tn, 2 Dn, 1 Pn (all exuviae?), Cadena, eclector, 26.4.2011, leg. Solórzano Kraemer (CNAN-UNAM); 1 +, Cadena, light trap, 26.4.2011, leg. Solórzano Kraemer (MNHN).

Remarks. When Banks (1895) described P. elongatus he did not compare it with any other species, but Tullgren (1900) later noted that it was very similar to P. nidificator. The differences used by Tullgren (1900) and Hoff (1946b) to separate the two species were largely invalidated when Hoff (1964) studied variation in a large number of specimens of $P$. elongatus from Florida. Hoff (1946c) listed P. elongatus as a questionable synonym of $P$. nidificator, but in his remarks concerning these species he indicated that it was better to continue to treat them as separate until more specimens had been studied. Curiously, Hoff (1964) did not reconsider the status of $P$. elongatus in the light of his results. Beier (1976b) suggested that $P$. elongatus was probably only a form of $P$. nidificator, but he did not synonymize them. Now that detailed descriptions of $P$. nidificator are available (Mahnert, 1979, 2013), there is no longer any justification for treating them as separate species, hence P. elongatus is here synonymized with $P$. nidificator.

The genus Trinidatemnus van den Tooren, 2008 was proposed for Trinidatemnus separatus van den Tooren, 2008, described from Trinidad. Van den Tooren (2008), noted that the external morphology of the genus was indistinguishable from that of Paratemnoides, but he separated them on the basis of the form of the male genitalia, particularly the lateral apodemes. The types of $T$. separatus are temporarily unavailable due to a relocation of the entomology collections of Naturalis, Leiden (Karen van Doorp, in litt.), but, based on the figure provided by van den Tooren (2008: fig. 8b), it is evident that what he took to be the lateral apodemes are in fact the outlines of the posterior diverticulum. Thus Trinidatemnus is here considered to be a junior subjective synonym of Paratemnoides. Comparison of the description of $T$. separatus with those of $P$. nidificator (Balzan, 1891-1892; Mahnert, 1979, 2013) reveals no significant differences, hence $T$. separatus is synonymized with $P$. nidificator.

The synonymy of $P$. elongatus with $P$. nidificator significantly increases the known distribution of the species, which now includes the southern United States (Florida), the Caribbean, Central America and tropical South America, reaching as far south as Paraguay and northern Argentina. It has previously been recorded from Mexico, as either $P$. nidificator (With, 1908) or P. elongatus (Muchmore, 1977), including Chiapas (Muchmore, 1992; Córdova-Tabares and Villegas-Guzmán, 2013). It is typically corticolous and has been recorded as phoretic on a variety of beetle families and sometimes on Cicadidae (Homoptera) and Hemiptera, (Lloyd and Muchmore, 1974; Aguiar and Bührnheim, 1998; Del-Claro and Tizo-Pedroso, 2009), or even the bee Apis mellifera Linnaeus, 1758 (Muchmore, 1971); additional insect groups and an arachnid (Opiliones) have been found to be used as vectors under laboratory conditions (TizoPedroso and Del-Claro, 2007). Although it was not collected at Coquitos, this species has been recorded from mangroves in the Galapagos Islands (Banks and Snodgrass, 1902) and Florida (Hoff, 1964), and I have seen material collected from this habitat on Guadeloupe $(1 \hat{\jmath}, 1 \stackrel{\rho}{\circ}$, Gosier, chemin littoral entre St Félix et la plage des Salines, mangrove, sous une écorce d'un tronc mort de mangle [Rhizophora mangle], 23 Sept. 2013, leg. J.-M. Lemaire; MNHN).

\author{
Family Chernetidae Menge, 1855 \\ Genus Americhernes Muchmore, 1976
}

\section{Americhernes oblongus (Say, 1821)}

Material examined. 1 (opisthosoma crumpled), La Cadena, pitfall trap, 22.6-2.7.2010 (CNAN-UNAM).

Remarks. This is the first record of A. oblongus from Mexico. This species is widely distributed in North America (Muchmore, 1976), but there is also an old record of uncertain validity from Cuba (Myers, 1927). Berger (1905) recorded A. oblongus from Jamaica, but judging from the large size reported for the specimens $(3.3-4.0 \mathrm{~mm})$, it seems likely that they were misidentified. The present specimen agrees well with the detailed description given by Muchmore (1976), except that the palps are slightly 
less robust (length/breadth ratios: femur 2.4, patella 2.1, chela- 2.9).

Genus Parachernes Chamberlin, 1931

Parachernes insuetus (Beier, 1933)

Figures 40, 43

Material examined. 1 (MNHN), Coquitos, Manglar, sweep-netting, 19.6.2010; 1 q (CNAN-UNAM), Coquitos, Malaise, 19.6-2.7.2010; $1 \hat{\delta}, 1$ (CNAN-UNAM), Coquitos, pitfall trap, 19.6-1.7.2010.

Description of female genitalia. Spermathecae with distinct, widely separate ducts, terminal bulbs pyriform, tapering at distal end (both foreshortened in fig. 43), a small number of gland ducts with tuberculate bases opening into distal part of spermathecal ducts, just before bulbs, no glands on rest of ducts or on bulbs; walls of bulbs thick; both spermathecae full of encysted spermatozoa in the single female cleared (specimen collected on 19.6.2010). Genital atrium large, membranous. Median cribriform plate large, contours ill defined, situated at base of genital atrium on dorsal side. Lateral cribriform plates elongate, extending along bases of gonosacs, gland pores larger than those of median cribriform plate; lateral apodemes large but not strongly sclerotized, making them rather inconspicuous;
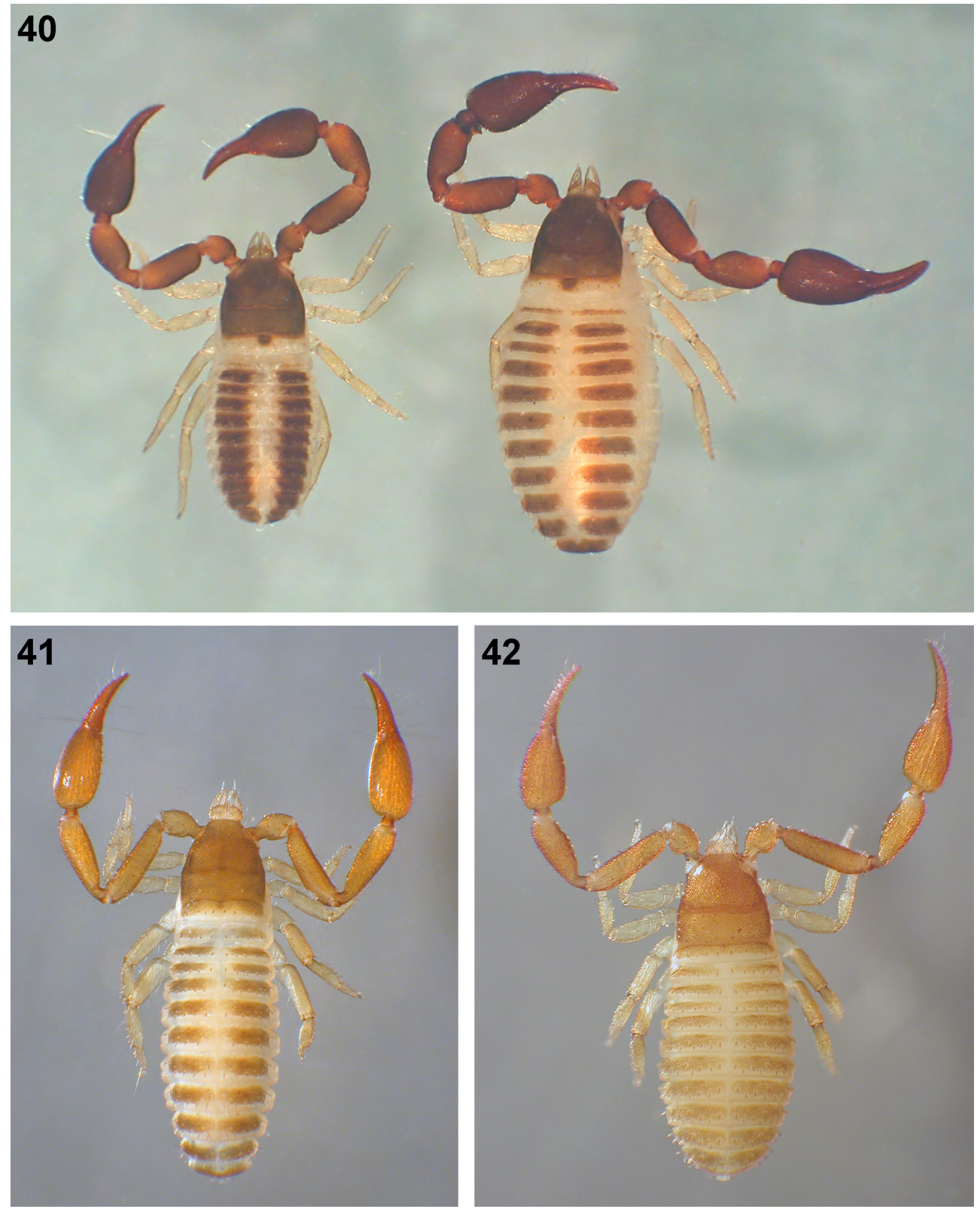

Figures 40-42, Extant Cheliferoidea from Chiapas. 40, Parachernes insuetus Beier, 1933, male (left) and female, dorsal view; 41, Dolichowithius aff. solitarius Hoff, 1945, female, dorsal view; 42, Withiidae, gen. sp. indet., female, dorsal view. 


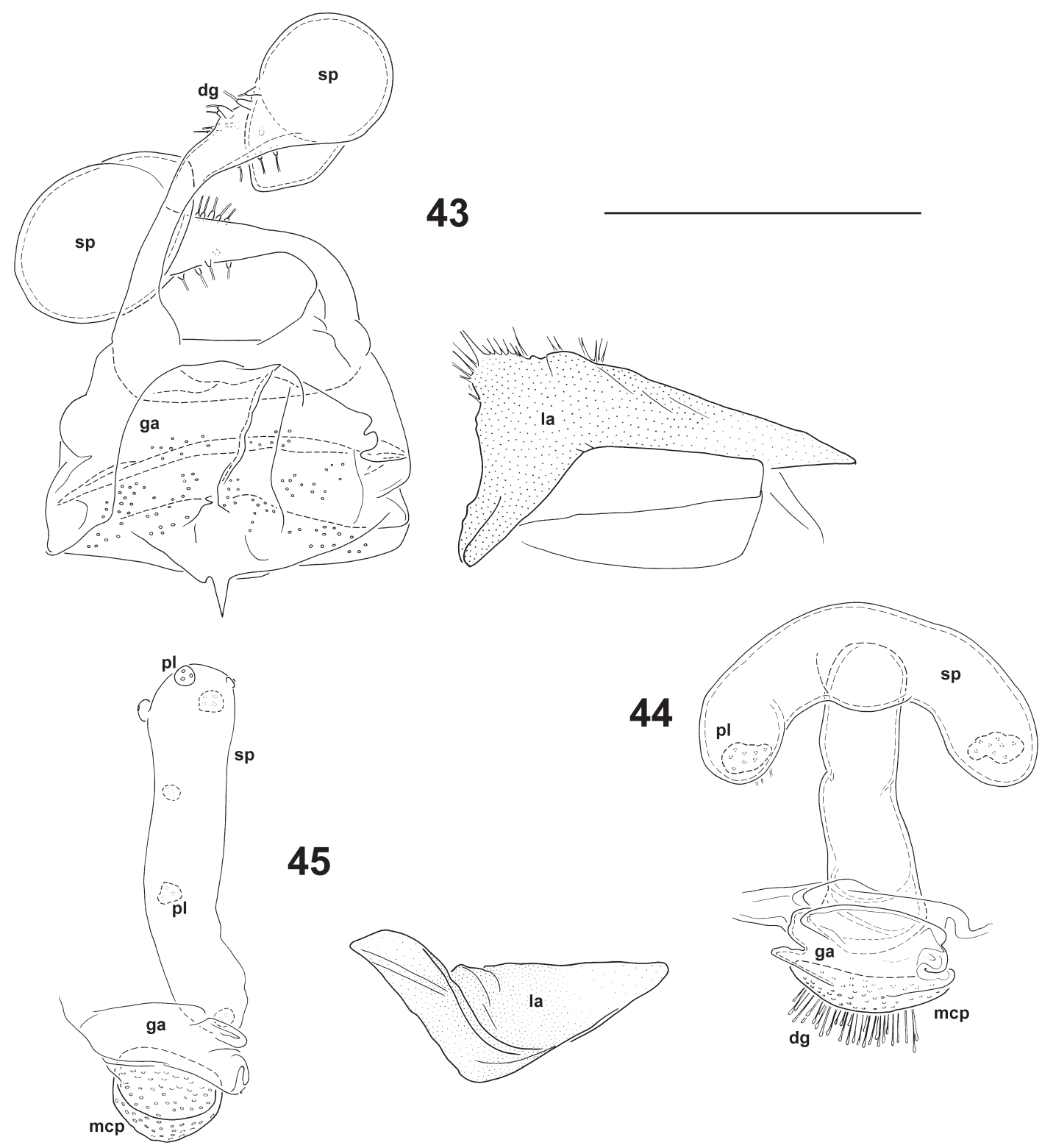

Figures 43-45, Females genitalia of extant Cheliferoidea from Chiapas, ventral view (gonosacs and lateral cribriform plates omitted). 43, Parachernes insuetus Beier, 1933, spermathecae, genital atrium and left lateral apodeme; 44, Dolichowithius aff. solitarius Hoff, 1945, spermatheca, genital atrium and median cribriform plate (lateral apodemes not shown); 45, Withiidae, gen. sp. indet., spermatheca, genital atrium, median cribriform plate and left lateral apodeme. Abbreviations: $d g$, gland duct; $g a$, genital atrium; $p l$, gland platelet; la, lateral apodeme; $s p$, spermatheca. Scale line: $0.1 \mathrm{~mm}$ (figures to same scale).

gonosacs of usual form for Chernetidae, neatly folded and arranged obliquely in retracted state, without gland pores.

Measurements. Male: body 1.8; carapace $0.65 \times 0.56$ (1.2); palp femur $0.51 \times 0.20(2.6)$, patella $0.50 \times 0.22$ (2.3), chela ${ }^{+} 0.91 \times 0.32(2.8)$, palm $^{+} 0.54$ (1.7), palm 0.48 (1.5), movable finger $0.44\left(0.92 \times\right.$ palm$\left.^{-}\right)$. Female: body 2.3 ; carapace $0.72-0.76 \times 0.64-0.72(1.2)$; palp femur $0.57-0.58$ $\times 0.22-0.23(2.5-2.6)$, patella $0.56-0.58(2.3-2.4)$, chela ${ }^{+}$ 1.09-1.11 (2.9), chela- $1.03-1.06$ (2.8), palm ${ }^{+} 0.64-0.68$ (1.7-1.8); palm- 0.59-0.61 (1.5-1.6), movable finger $0.50-0.51\left(0.73-0.85 \times\right.$ palm $\left.^{-}\right)$.

Remarks. This species was previously known only from Veracruz, Mexico (Beier, 1933). The specimens from Coquitos agree with the brief original description, except that the eyes are quite obvious, whereas Beier (1933) describes the types as having only weak eye-spots (Augenflecke wenig deutlich). Beier (1933) also described the desclerotized part of the carapace as being greenish, whereas it is off-white in the present specimens, but it is possible that Beier's specimens were teneral.

Family Withiidae Chamberlin, 1931 Genus Dolichowithius Chamberlin, 1931 
Dolichowithius aff. solitarius Hoff, 1945

Figures 41, 44

Material examined. 1 , La Cadena, open eclector, fallen tree, 26.6-2.7.2010 (CNAN-UNAM).

Description of female genitalia. Spermatheca (Fig. 44) T-shaped, branches curved and as thick as stem; end of branches each with a single plate of gland pores. Genital atrium small. Median cribriform plate large and oval (strongly foreshortened in Fig. 44); lateral cribriform plates compact, oval. Lateral apodemes well developed. The female examined had both branches of the spermatheca filled with encysted spermatozoa, but the trunk was largely empty.

Measurements. Body 2.2. Carapace $0.61 \times 0.48(1.3)$. Palp femur $0.59 \times 0.15(3.9)$, patella $0.61 \times 0.17$ (3.6), chela ${ }^{+}$ $0.95 \times 0.27(3.5)$, chela $0.89(3.3)$, palm $^{+} 0.57(2.1)$, palm $0.50(1.9)$, movable finger $0.43\left(0.85 \times\right.$ palm $\left.^{-}\right)$. Leg I 0.135 $\times 0.119(1.1)$, patella $0.25 \times 0.11(2.2)$, tibia $0.27 \times 0.07$ (3.9), tarsus $0.27 \times 0.05$ (5.3). Leg IV femur $0.19 \times 0.13$ (1.4), patella $0.41 \times 0.18(2.3)$, femoropatella $0.50(2.8)$, tibia $0.40 \times 0.10(4.1)$, tarsus $0.34 \times 0.06(5.9)$.

Remarks. The genus Dolichowithius is widely distributed in Central America, the Caribbean and South America, but this is the first time that it has been recorded from Mexico. In the absence of males, it is not possible to identify the species with certainty. The female is similar to that of D. mediofasciatus Mahnert, 1979, from the Amazon of Brazil (Mahnert, 1979), but it differs from the latter in having the branches of the spermatheca longer and thinner. D. mediofasciatus is in turn very similar to D. solitarius Hoff, 1945, which is only known from a male collected in Costa Rica (Hoff, 1945). The male of $D$. mediofasciatus differs from that of D. solitarius in having slightly more robust palp segments (Mahnert, 1979). Assuming that the degree of sexual dimorphism is similar in both species, the female of $D$. solitarius could be expected to have slightly more elongate palp segments than those of D. mediofasciatus or the Mexican specimen, but this assumption might be incorrect. Mahnert (1979) also separated $D$. mediofasciatus from $D$. solitarius on the basis of colour pattern, but the validity of that comparison is doubtful: the male Hoff (1945) examined was of unknown age and may have faded, in addition to which it would presumably have been treated with potassium hydroxide, as per Hoff's (1949) usual method, which can have a bleaching effect. Hoff (1945) does not seem to have considered the absence of a pattern in the holotype of $D$. solitarius to be of any significance, since he made no reference to it in his comparisons with other species of the genus, even though the pattern in at least one of those he mentioned- $D$. extensus Beier, 1932 (as described by With (1908) under the misidentification Chelifer longichelifer) - is similar to that of D. mediofasciatus.
Withiidae gen. sp. indet. Figures 42, 45

Material examined. 1 , Coquitos, pitfall trap, 19.61.7.2010 (CNAN-UNAM); 1 +, La Cadena, open eclector, 16.4.2011 (MNHN); $1 \mathrm{Tn}$, Cadena, open eclector, 26.4.2011; 2 Dn, La Cadena, eclector, 16.4.2011 (CNAN-UNAM).

Description of female genitalia. Spermatheca (Fig. 45) tubular, directed anteriorly and reaching as far as posterior margin of coxae IV, dorsal and terminal faces with a total of 7 groups of raised gland pores, each group comprising 2-4 pores. Genital atrium small. Median cribriform plate bowl-shaped. Lateral cribriform plate compact, longoval. Gonosacs irregularly plicate. Lateral apodeme well developed.

Measurements of females. Body 1.9. Carapace $0.64-0.65 \times 0.64$ (1.0). Palp femur 0.59-0.68 $\times 0.15-0.16$ (4.1), patella $0.54-0.61 \times 0.18-0.19(3.1-3.2)$, chela ${ }^{+}$ $0.93-1.01 \times 0.27-0.31(3.3-3.5)$, chela- $0.90-0.96(3.1-3.4)$, palm $^{+} 0.50-0.58$ (1.9), palm $0.45-0.50$ (1.6-1.7), movable finger $0.47-0.51(1.0-1.1 \times$ palm $)$.

Remarks. These females appear to belong to an undescribed species that cannot be readily assigned to a genus. It is characterized by its strong granulation, strongly clavate dorsal setae, the absence of tactile setae on tergite XI, the presence of paired gland setae on sternites VIII and IX, the long, unpaired tubular spermatheca and the short tactile seta on leg IV, which is situated near the distal end. It might perhaps belong to the genus Balanowithius Beier, 1959, but it is difficult to draw any conclusions in the absence of males.

\section{Conclusions}

The pseudoscorpion fauna of Mexican amber fauna is now known to include seven or eight species, representing four families. However, it is still very poorly known, because most of the species have not yet been formally named and many others certainly await discovery. The available fossils suggest that the fauna was similar to that currently present in Mesoamerica or even Chiapas, which is not surprising, given that the Miocene age of the amber is young in terms of pseudoscorpion evolution. It is also consistent with the assumptions of similar climatic conditions to those now found in the region and an overall stability of its ecosystems, as discussed by Solórzano Kraemer (2007). A meaningful comparison with the Dominican amber fauna is not yet possible because the latter has not yet been adequately studied. The biogeographic usefulness of the fossils studied here is quite limited because most of them belong, as one would expect, to corticolous groups. These are almost always phoretic and the genera concerned tend to be widely distributed and can occur in a fairly wide range of forest types. Although the halophilic genus Paraliochthonius has strict habitat preferences, it is also very widely distributed along the coasts of the world. A final problem 
for making comparisons is that the litter or soil-dwelling pseudoscorpions of Mexico have been little studied in comparison with phoretic or cave-dwelling species. The only representative of a litter-dwelling group in the fossils studied here is the Tyrannochthonius species from Totolapa, but it provides little biogeographic information because the pseudoscorpions of this habitat are rather inadequately known for Mexico and Central America. Muchmore (1992) noted that undescribed representatives of Tyrannochthonius are very common in Chiapas, but there is still only one species of this genus described from Mexico.

A comparison of the pseudoscorpions found in Mexican amber with extant species recorded in Mexican mangroves, or with fossil species described from Dominican amber might give the impression that they each contain very different faunas, since there are few genera in common. These differences cannot, however, be considered significant because the number of species concerned in each case no doubt represents only a small fraction of those actually present.

\section{Acknowledgements}

I am indebted to Mónica Solórzano Kraemer (SMF), Francisco Vega (Instituto de Geología, UNAM, Coyoacán), Lourdes Roja and Thomas Hegna (Peabody Museum of Natural History, Yale University), Gunter Bechly (SMNS), Andrew Ross (NMS), David Coty (MNHN), Jean-Michel Lemaire (Muséum d'Histoire naturelle de Nice) and the late Joachim Adis (Max-Planck-Institute for Limnology, Plön) for making available the material studied here. Very helpful comments on the manuscript were made by Volker Mahnert (Muséum d'Histoire naturelle de Genève) and Juan A. Zaragoza (Universidad de Alicante).

\section{References}

Aguiar, N.O., Bührnheim, P.F., 1998, Phoretic pseudoscorpions associated with flying insects in Brazilian Amazonia: Journal of Arachnology, $26,452-456$.

Baert, L., Mahnert, V. 2015, The distribution of the non-araneae and nonacari arachnids of Galápagos: Belgian Journal of Entomology, 28, 1-76, available at $<\mathrm{http} / / \mathrm{www}$.srbe-kbve.be/cm/belgian-journalentomology-online>, accessed 19 May 2015.

Balzan, L. [as Aloysius Balzan], 1888, Chernetidae nonnullae SudAmericanae. Pugillus III: Asunción, Paraguay, published by the author. 4 plates with accompanying text (unpaginated).

Balzan, L., 1891-1892, Voyage de M. E. Simon au Venezuela (Décembre 1887 - Avril 1888). Arachnides. Chernetes (Pseudoscorpiones): Annales de la Société entomologique de France, 60, (2/3, 1891) 497-512, (4, 1892) 513-552.

Banks, N., 1895, Notes on the Pseudoscorpionida: Journal of the New York Entomological Society, 3, 1-13.

Banks, N., 1902, Papers from the Hopkins Stanford Galápagos Expedition, 1898-1899. VII. Entomological results (6), Arachnida, by N. Banks and field notes by R.E. Snodgrass: Proceedings of the Washington
Academy of Sciences, 4, 49-86.

Banks, N., 1904, The Arachnida of Florida: Proceedings of the Academy of Natural Sciences of Philadelphia, 56, 120-147, pls VII-VIII.

Banks, N., Snodgrass, R.E., 1902, Papers from the Hopkins Stanford Galapagos Expedition, 1898-1899. VII. Entomological results (6). Arachnida: Proceedings of the Washington Academy of Sciences, 4, 49-86, pls I-III.

Bedoya-Roqueme, E., 2015, Una nueva especie de Paraliochthonius (Pseudoscorpiones: Chthoniidae: Tyrannochthoniini) de Colombia: Revista Ibérica de Aracnología, 26, 49-54.

Beier, M., 1932a, Pseudoscorpionidea II. Subord. C. Cheliferinea: Das Tierreich, 58: i-xxi, 1-294.

Beier, M., 1932b, Zur Kenntnis der Lamprochernetinae (Pseudoscorp.): Zoologischer Anzeiger, 97, 258-267.

Beier, M., 1933, Pseudoskorpione aus Mexiko: Zoologischer Anzeiger, 104, 91-101.

Beier, M., 1951, Die Pseudoscorpione Indochinas: Mémoires du Muséum National d'Histoire Naturelle, Paris, nouvelle série, 1, 47-123.

Beier, M., 1955, Pseudoscorpione im baltischen Bernstein aus dem Geologischen Staatsinstitut in Hamburg: Mitteilungen aus dem Geologischen Staatsinstitut in Hamburg, 24, 48-54.

Beier, M., 1956, Ein neuer Blothrus (Pseudoscorp.) aus Sardinien, und ueber zwei Pseudoscorpione des westmediterranen Litorals: Fragmenta Entomologica, 2, 55-63.

Beier, M., 1959, Zur Kenntnis der Pseudoscorpioniden-Fauna des Andengebiets: Beiträge zur neotropischen Fauna, 1, 185-228.

Beier, M., 1976a, Neue und bemerkenswerte zentralamerikanische Pseudoskorpione aus dem Zoologischen Museum in Hamburg: Entomologische Mitteilungen aus dem Zoologischen Museum Hamburg, 5 (91), 1-5.

Beier, M., 1976b, Pseudoscorpione von der Dominicanischen Republik (Insel Haiti): Revue suisse de Zoologie, 83, 45-58.

Berger, E.W., 1905, Habits and distribution of the Pseudoscorpionidae, principally Chelanops oblongus, Say: Ohio Naturalist, 6, 407-419.

Boucot, A.J., Poinar G.O., 2010, Fossil behavior compendium: Boca Raton, Florida, CRC Press, $391 \mathrm{p}$.

Bryant, D.D., 1983, A recently discovered amber source near Totolapa, Chiapas, Mexico: American Antiquity, 48, 354-357.

Caporiacco, L. di, 1947, Diagnosi preliminari di specie nuove di Aracnidi della Guiana Britannica raccolte dai professori Beccari e Romiti: Monitore Zoologico Italiano, 56, 20-34.

Chamberlin, J.C., 1923, New and little known pseudoscorpions, principally from the islands and adjacent shores of the Gulf of California: Proceedings of the California Academy of Sciences, 12 (4), 353-387.

Chamberlin, J.C., 1929, A synoptic classification of the false scorpions or chela-spinners, with a report on a cosmopolitan collection of the same. Part I. The Heterosphyronida (Chthoniidae) (Arachnida - Chelonethida): Annals and Magazine of Natural History, 10 (4), $50-80$.

Chamberlin, J.C., 1930, A synoptic classification of the false scorpions or chela-spinners, with a report on a cosmopolitan collection of the same. Part II. The Diplosphyronida (Arachnida-Chelonethida): The Annals and Magazine of Natural History, 10 (5), 1-48, 585-620, figs. 1-3.

Chamberlin, J.C., 1931, The arachnid order Chelonethida: Stanford University Publications (Biological Sciences), 7 (1), 1-284.

Chamberlin, J.C., 1932, A synoptic revision of the generic classification of the chelonethid family Cheliferidae Simon (Arachnida) (continued): The Canadian Entomologist, 64, 17-21.

Chamberlin, J.C., Chamberlin, R.V., 1945, The genera and species of the Tridenchthoniidae (Dithidae), a family of the arachnid order Chelonethida: Bulletin of the University of Utah, 35 (23) (Biological Series), 9 (2), 1-67.

Córdova-Tabares, V.M., Villegas-Guzmán, G.A., 2013, Nuevos registros de Pseudoescorpiones (Arachnida: Pseudoscorpiones) en Chiapas, México: Acta Zoológica Mexicana, 29, 596-613. 
Coty, D., Aria, C., Garrouste, R., Wils, P., Legendre, F., Nel, A., 2014 The first ant-termite syninclusion in amber with CT-scan analysis of taphonomy: PLOS ONE 9(8), e104410. Online journal, available at $<$ http://journals.plos.org/plosone/article?id=10.1371/journal. pone.0104410>, accessed 19 May 2015.

Ćurčić, B.P.M., 2008, Ayyalonia dimentmani n. g., n. sp. (Ayyaloiini n. trib., Chthoniidae, Pseudoscorpiones) from a cave in Israel: Archives of Biological Sciences, Belgrade, 60 (3), 331-339.

Daday, J., 1889a, A Magyar Nemzeti Muzeum álskorpióinak áttekintése: Természetrajzi Füzetek, 11 (3-4), 111-136, pl. 4.

Daday, J. [as 'Daday, E. v.'], 1889b, Übersicht der Chernetiden des Ungarischen Nationalmuseums in Budapest: Természetrajzi Füzetek, 11 (3-4), 165-192, pl. 4.

Del-Claro, K., Tizo-Pedroso, E., 2009, Ecological and evolutionary pathways of social behavior in Pseudoscorpions (Arachnida: Pseudoscorpiones): Acta Ethologica, 12, 13-22.

Durán-Ruiz, C., Riquelme, F. Coutiño-José, M. Carbot-Chanona, G. Castaño-Meneses G., Ramos-Arias, M., 2013, Ants from the Miocene Totolapa amber (Chiapas, México), with the first record of the genus Forelius (Hymenoptera, Formicidae): Canadian Journal of Earth Sciences, 50, 495-502.

Gabbutt, P.D., 1972, Some observations of taxonomic importance on the family Chernetidae (Pseudoscorpiones): Bulletin of the British Arachnological Society, 2 (5), 83-86.

Gabbutt, P.D., Vachon, M., 1963, The external morphology and life history of the pseudoscorpion Chthonius ischnocheles (Hermann): Proceedings of the Zoological Society of London, 140, 75-98.

Harvey, M.S., 1991a, Catalogue of the Pseudoscorpionida: Manchester, Manchester University Press, 726 p.

Harvey, M.S., 1991b, Notes on the genera Parahya Beier and Stenohya Beier (Pseudoscorpionida: Neobisiidae): Bulletin of the British arachnological Society, 8, 288-292.

Harvey, M.S., 1994, Redescription and the systematic position of the Brazilian genus Xenochernes Feio (Pseudoscorpionida: Chernetidae): Journal of Arachnology, 22, 131-137.

Harvey, M.S., 1995, Barbarella gen. nov. and Cacoxylus Beier (Pseudoscorpionida: Chernetidae), two remarkable sexually dimorphic pseudoscorpions from Australasia: Records of the Western Australian Museum, supplement 52, 199-208.

Harvey, M.S., 2009, The first Australasian species of the halophilic pseudoscorpion genus Paraliochthonius (Pseudoscorpiones: Chthoniidae): Records of the Western Australian Museum, 25 , 329-344.

Harvey, M.S., 2013, Pseudoscorpions of the World, version 3.0 (on-line) Perth, Western Australian Museum, available at $<\mathrm{http}: / /$ museum wa.gov.au/catalogues-beta/pseudoscorpions $>$, accessed 9 April 2015 .

Hoff, C.C., 1945, Two new pseudoscorpions of the genus Dolichowithius: American Museum Novitates, 1300, 1-7

Hoff, C.C., 1946a, Three new species of heterosphyronid pseudoscorpions from Trinidad: American Museum Novitates, 1322, 1-13.

Hoff, C.C., 1946b, A redescription of Atemnus elongatus Banks, 1895: Proceedings of the New England Zoölogical Club, 23, 109-112.

Hoff, C.C., 1946c, New pseudoscorpions, chiefly Neotropical, of the suborder Monosphyronida: American Museum Novitates, 1318, $1-32$.

Hoff, C.C., 1949, The pseudoscorpions of Illinois: Bulletin of the Illinois Natural History Survey, 24, 6 unnumbered pages $+413-498$

Hoff, C.C., 1959, The pseudoscorpions of Jamaica. Part 1. The genus Tyrannochthonius: Bulletin of the Institute of Jamaica, (Science) $10,1-39$.

Hoff, C.C., 1964, Atemnid and cheliferid pseudoscorpions, chiefly from Florida: American Museum Novitates, 2198, 1-43.

Hoffeins, C., 2012, On Baltic amber inclusions treated in an autoclave: Polish Journal of Entomology (Polskie Pismo Entomologiczne), $81,165-183$

Hounsome, M.V., 1980, Geography and ecology of Little Cayman. 8. The terrestrial fauna (excluding birds and insects) of Little Cayman: Atol
Research Bulletin, 241, 81-90.

Judson, M.L.I., 2000, Electrobisium acutum Cockerell, a cheiridiid pseudoscorpion from Burmese amber, with remarks on the validity of the Cheiridioidea (Arachnida, Chelonethi): Bulletin of the Natural History Museum, London, (Geology) 56 (1), 79-83.

Judson, M.L.I., 2007, First fossil record of the pseudoscorpion family Pseudochiridiidae (Arachnida, Chelonethi, Cheiridioidea) from Dominican amber: Zootaxa, 1393, 45-51.

Judson, M.L.I., 2010, Redescription of Chelifer eucarpus Dalman (Arachnida, Chelonethi, Withiidae) and first records of pseudoscorpions in Madagascan and Colombian copal: Palaeodiversity, 3, 33-42.

Klausen, F.E., 2005, The male genitalia of the family Atemnidae (Pseudoscorpiones): Journal of Arachnology, 33, 641-662.

Langenheim, J.H., Hackner, B.L., Bartlett, A., 1967, Mangrove pollen at the depositional site of Oligo-Miocene amber from Chiapas, Mexico: Botanical Museum Leaflets, Harvard University, 21, 289-324.

Lee, V.F., 1979, The maritime pseudoscorpions of Baja California, México (Arachnida: Pseudoscorpionida): Occasional Papers of the California Academy of Sciences, 131, i-iv + 1-38.

Legg, G., 1987, Proposed taxonomic changes to the British pseudoscorpion fauna (Arachnida): Bulletin of the British Arachnological Society, 7, 179-182.

Lloyd, J.E., Muchmore, W.B., 1974, Pseudoscorpions phoretic on fireflies: Florida Entomologist, 57, 381.

Mahnert, V., 1978, Pseudoskorpione (ausgenommen Olpiidae, Garypidae) aus Congo-Brazzaville (Arachnida, Pseudoscorpiones): Folia entomologica Hungarica, (n.s.) 31, 69-133.

Mahnert, V., 1979, Pseudoskorpione (Arachnida) aus dem AmazonasGebiet (Brasilien): Revue suisse de Zoologie, 86, 719-810.

Mahnert, V., 1985a, Weitere Pseudoskorpione (Arachnida) aus dem Amazonasgebiet (Brasilien): Amazoniana, 9, 215-241.

Mahnert, V., 1985b, Pseudoscorpions (Arachnida) from the Lower Amazon Basin: Revista Brasileira de Zoologia, 29, 75-80.

Mahnert, V., 2011, A nature's treasury: pseudoscorpion diversity of the Canary Islands, with the description of nine new species (Pseudoscorpiones, Chthoniidae, Cheiridiidae) and new records: Revista Ibérica de Aracnología, 19, 27-45.

Mahnert, V., 2013, The identities of two pseudoscorpion species (Arachnida) described from Guyana by L. di Caporiacco: Arachnology, 16, 16-20.

Mahnert, V., 2014, Pseudoscorpions (Arachnida: Pseudoscorpiones) from the Galapagos Islands (Ecuador): Revue suisse de Zoologie, 121, 135-210.

Malcolm, D.R., Muchmore, W.B., 1985, An unusual species of Tyrannochthonius from Florida (Pseudoscorpionida, Chthoniidae): Journal of Arachnology, 13, 403-405.

Menozzi, C., 1924, Nuova specie di Pseudoscorpione alofilo: Annuario del Museo Zoologico della Università di Napoli, 5, 1-3.

Muchmore, W.B., 1971, Phoresy by North and Central American pseudoscorpions: Proceedings of the Rochester Academy of Science, $12,77-97$.

Muchmore, W.B., 1972, Observations on the classification of some European chernetid pseudoscorpions: Bulletin of the British Arachnological Society, 2 (6), 112-115.

Muchmore, W.B., 1976, Pseudoscorpions from Florida and the Caribbean Area. 5. Americhernes, a new genus based upon Chelifer elongatus Say (Chernetidae): Florida Entomologist, 59, 151-163.

Muchmore, W.B., 1977, Preliminary list of the pseudoscorpions of the Yucatan peninsula and adjacent regions, with descriptions of some new species (Arachnida: Pseudoscorpionida): Association for Mexican Cave Studies Bulletin, 6, 63-78.

Muchmore, W.B., 1979, Pseudoscorpions from Florida and the Caribbean Area. 7. Floridian diplosphyronids: Florida Entomologist, 59, 193-213.

Muchmore, W.B., 1981, Pseudoscorpions from Florida and the Caribbean Area 11. A new Parachelifer from the Virgin Islands (Cheliferidae): Florida Entomologist, 64, 189-191. 
Muchmore, W.B., 1992, Pseudoscorpionida, in Navarro, L., Robinson, D., Robinson, J.G. (Eds), Diversidad biológica en la Reserva de la Biosfera de Sian Ka'an Quintana Roo, México, Vol. 2: Chetumal, Centro de Investigaciones de Quintana Roo and University of Florida Program of Studies in Tropical Conservation, 155-173.

Muchmore, W.B., 1997, On the status of four old species of pseudoscorpions from Puerto Rico and the Virgin Islands (Pseudoscorpionida: Olpiidae, Chernetidae, Withiidae): Caribbean Journal of Science, $33,269-280$.

Muchmore, W.B., Alteri, C., 1974, The genus Parachernes (Pseudoscorpionida, Chernetidae) in the United States, with descriptions of new species: Transactions of the American Entomological Society, 99, 477-506.

Myers, J.G., 1927, Ethological observations on some Pyrrhocoridae of Cuba (Hemiptera-Heteroptera): Annals of the entomological Society of America, 20, 279

Perrilliat, M.C., Vega, F.J., Coutiño, M.A., 2010, Miocene mollusks from the Simojovel area in Chiapas, southwestern Mexico: Journal of South American Earth Sciences, 30, 111-119.

Reyes-Castillo, P., Hendrichs, J., 1975, Pseudoscorpiones asociados con pasálidos: Acta Politécnica Mexicana, 26, 129-133.

Riquelme, F., Piedra-Jiménez, D.F., Córdova-Tabares, V., Luna-Castro, B., 2014a, A new chernetid pseudoscorpion from the Miocene Chiapas - amber Lagerstätte, Mexico: Canadian Journal of Earth Sciences, 51, 902-908.

Riquelme, F., Ruvalcaba-Sil, J.L, Alvarado-Ortega, J., Estrada-Ruiz, E., Galicia-Chávez, M., Porras-Múzquiz, H., Stojanoff, V., Siddons, D.P., Miller, L., 2014b, Amber from México: Coahuilite, Simojovelite and Bacalite, in Sil, J.L.R., Trujeque, J.R., Castro, A.V., Pesqueira, M.E. (eds), 2013 IMRC Meeting, Symposium 8A: Cultural Heritage and Archaeological Issues in Materials Science: Materials Research Society Online Proceedings Library, 1618, 12 p., doi 10.1557/opl.2014.466.

Ross, A., Sheridan, A., 2013, Amazing Amber: the challenges of creating an exhibition on amber and possible solutions, in KosmowskaCeranowicz, B., Gierlowski, W., Sontag, E. (eds), Proceedings of the International Researcher Symposium "Amber. ResearchCollections-The Market", 22-23 March 2013, Gdansk, Poland: Gdansk, Gdańsk International Fair Co., 92-94.

Schawaller, W., 1982, Der erste Pseudoskorpion (Chernetidae) aus Mexicanischem Bernstein (Stuttgarter Bernsteinsammlung: Arachnida, Pseudoscorpionidea): Stuttgarter Beiträge zur Naturkunde, (B) 85, 1-9.

Simberloff, D.S., Wilson, E.O., 1969, Experimental zoogeography of islands: the colonization of empty islands: Ecology, 50, 278-296.

Solórzano Kraemer, M.M., 2007, Systematic, palaeoecology, and palaeobiogeography of the insect fauna from Mexican amber: Palaeontographica, (A) 282 (1-6), 1-133, pls 1-14.
Solórzano Kraemer, M.M., 2010, Mexican amber, in Penney, D. (ed.), Biodiversity of fossils in amber from the major world deposits: Manchester, Siri Scientific Press, 42-56.

Solórzano Kraemer, M.M., Kraemer, A.S, Stebner, F., Bickel, D.J, Rust, J., 2015, Entrapment bias of insects in Miocene amber revealed by trapping experiments in a tropical forest in Chiapas, Mexico: PLOS One, 10 (3), e0118820, 1-24, on-line journal, available at $<\mathrm{http}: / /$ dx.doi.org/10.1371/journal.pone.0118820>, accessed 19 May 2015.

Solórzano Kraemer, M.M., Rust, J., 2006, Der Mexikanische Bernstein und seine Einschlüsse: Fossilien, Zeitschrieft für Hobbypaläontologen, $6,337-340$

Solórzano Kraemer, M.M., Stebner, F., 2013, Paleocomunidades y comunidades. Comparación de la fauna insectil fossil del ámbar mexicano con la fauna insectil de la costa del pacifico de Chiapas: Entomología Mexicana, 11 (1), 27-31.

Tizo-Pedroso, E., Del-Claro, K., 2007, Cooperation in the neotropical pseudoscorpion, Paratemnoides nidificator (Balzan, 1888): feeding and dispersal behavior: Insectes Sociaux, 54, 124-131.

Tömösváry, O., 1882, Pseudoscorpiones Faunae Hungari - cae. A Magyar fauna álskorpiói: Magyar Tudományos Akadémia Matematikai és Természettudományi Kö - zlemények, 18, 135-256.

Tooren, D. van den, 2008, New Neotropical pseudoscorpions (Pseudoscorpiones) from Aruba, Trinidad and Saba (Lesser Antilles), with some new localities of pseudoscorpions from Aruba and Bonaire: Zoologische Mededelingen, 82 (40), 423-440.

Tullgren, A., 1900, Two new species of Chelonethi (pseudoscorpions) from America: Entomologisk Tidskrift, 21, 153-157.

Vachon, M., 1963, Chthonius (C.) balazuci, nouvelle espèce de Pseudoscorpion cavernicole du département français de l'Ardèche (Heterosphyronida, Chthoniidae). Bulletin du Muséum National d'Histoire Naturelle, Paris, (2) 35, 394-399.

Villegas-Guzmán, G.A., Pérez, T.M., 2005, Pseudoescorpiones (Arachnida: Pseudoscorpionida) asociados a nidos de ratas del género Neotoma (Mammalia: Rodentia) del altiplano mexicano: Acta Zoológica Mexicana, (n.s.) 21, 63-77.

With, C.J., 1908, An account of the South-American Cheliferinae in the collections of the British and Copenhagen Museums: Transactions of the zoological Society of London, 18, 217-340, pls 29-31.

Manuscript received: March 2, 2015.

Corrected manuscript received: June 1, 2015.

Manuscript accepted: June 8, 2015. 